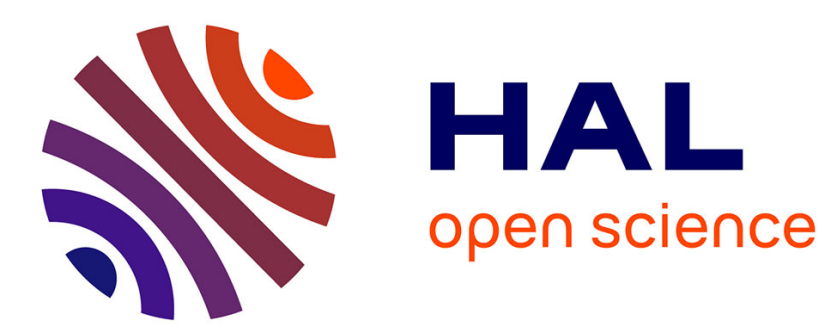

\title{
Crisis at Home: Mancession-induced Change in Intrahousehold Distribution
}

Olivier Bargain, Laurine Martinoty

\section{To cite this version:}

Olivier Bargain, Laurine Martinoty. Crisis at Home: Mancession-induced Change in Intrahousehold Distribution. Journal of Population Economics, 2019, 32, pp.277-308. 10.1007/s00148-018-0696-x . hal-01770180

\section{HAL Id: hal-01770180 \\ https://hal.science/hal-01770180}

Submitted on 18 Apr 2018

HAL is a multi-disciplinary open access archive for the deposit and dissemination of scientific research documents, whether they are published or not. The documents may come from teaching and research institutions in France or abroad, or from public or private research centers.
L'archive ouverte pluridisciplinaire HAL, est destinée au dépôt et à la diffusion de documents scientifiques de niveau recherche, publiés ou non, émanant des établissements d'enseignement et de recherche français ou étrangers, des laboratoires publics ou privés. 


\title{
Crisis at Home: \\ Mancession-induced Change in Intrahousehold Distribution ${ }^{+}$
}

\author{
Olivier Bargain* $\quad$ Laurine Martinoty**
}

January 31, 2018

\begin{abstract}
The Great Recessions was essentially a 'mancession' in countries like Spain, the UK or the US, i.e. it hit men harder than women for they were disproportionately represented in heavily affected sectors. We investigate how the mancession, and more generally women's relative opportunities on the labor market, translate into within-household redistribution. Precisely, we estimate the spouses' resource shares in a collective model of consumption, using Spanish data over 2006-2011. We exploit the gender-oriented evolution of the economic environment to test two original distribution factors: first the regional-time variation in spouses' relative unemployment risks, then the gender-differentiated shock in the construction sector (having a construction sector husband after the outburst of the crisis). Both approaches conclude that the resource share accruing to Spanish wives increased by around 7-9 percent on average, following the improvement of their relative labor market positions. Among childless couples, we document a 5-11 percent decline in individual consumption inequality following the crisis, which is essentially due to intrahousehold redistribution.
\end{abstract}

Keywords: mancession, intrahousehold allocation, unemployment risk JEL: C3, D12, D13

+ We thank the two anonymous referees for their many valuable comments and suggestions. We are also grateful to Olivier Donni, Frederic Vermeulen and participants to the ADRES conference and to seminars at ISER (Essex), THEMA (Cergy-Pontoise), AMSE (Aix-Marseille) and LEO (Orleans) for their helpful suggestions. All errors remain ours. Corresponding author: Olivier Bargain, AixMarseille School of Economics, GREQAM, Chteau Lafarge, Route des Milles, 13290 Les Milles, France, olivier.bargain@univ-amu.fr

* Aix-Marseille University (Aix-Marseille School of Economics), CNRS \& EHESS, and IZA.

** Centre d'Économie de la Sorbonne, Université Paris 1, France 


\section{Introduction}

Downturns are sometimes thought of as primarily affecting the employment of men, hence characterized as 'mancessions'. If not always, this was particularly the case during the Great Recession. In countries like Spain and the US, although women did experience substantial job losses, the crisis hit men harder than women for they were disproportionately represented in heavily affected sectors such as construction, manufacturing and financial services. Figure 1 displays the unemployment gap between men and women aged 20-44 in these two countries, where unemployment doubled between 2007 and 2009 (from $4.6 \%$ to $9.3 \%$ in the US and from $8.2 \%$ to $17.8 \%$ in Spain ${ }^{1}$ ). Even though starting points are different (women's unemployment rates relative to men's were much higher in Spain before the crisis), the trend is very similar in both countries, with a sharp decline in the relative unemployment of women.

FiguRE 1 - Unemployment Rate by Gender, 2006-2011

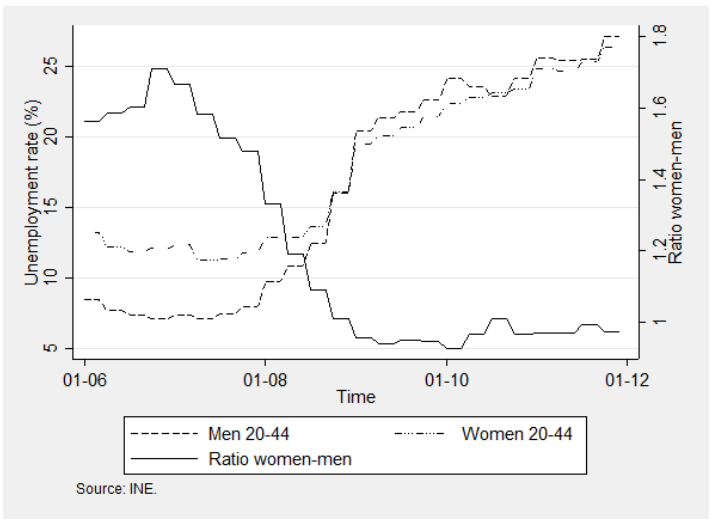

(A) Spain

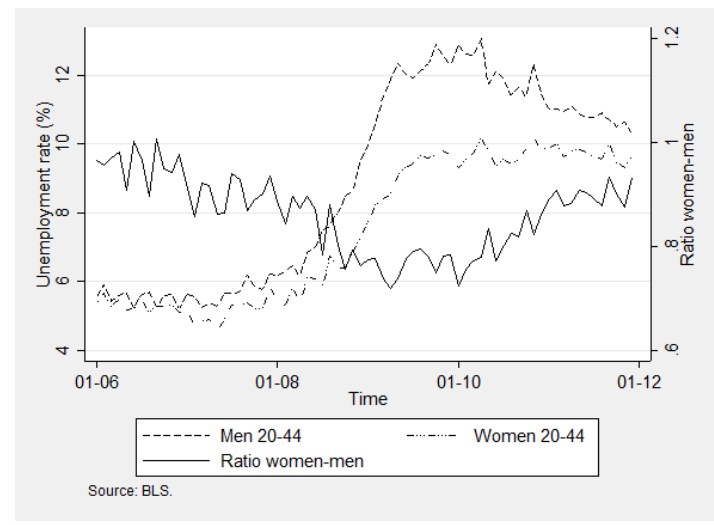

(B) United States

It is likely that such a large asymmetrical shock on spouses' labor market opportunities has affected household decision making and, possibly, the way spouses share resources. To date, there is hardly any empirical evidence on how the mancession has translated within the household. More generally, very little is known about the way labor market opportunities, and the way they change after a shock, affect intrahousehold distribution. The main reason for this lack of evidence is certainly the difficulty to control for unobserved households characteristics that can simultaneously influence consumption patterns and spouses' actual (un)employment status. One may argue that this is less of an issue for such an unanticipated, large-scope and mainly demand-side driven shock as the Great Recession. At the very least, it seems plausible to assume exogeneity regarding how the

\footnotetext{
${ }^{1}$ Source: OECD. Main Economic Indicators. Labour: Labour market statistics.
} 
risk of unemployment has impacted household decisions. The other reason is practical: we hardly observe what happens within households (and in particular how resources are distributed). Nonetheless, recent advances in collective models provide a way to estimate sharing within families.

In this paper, we push forward these two ideas. We exploit the Spanish mancession as a natural experiment to investigate how a change in the gender unemployment gap translated into the household. Intrahousehold distribution, and its evolution during the Great Recession, is inferred from the estimation of a collective model identified on observations from both singles and couples without children. The model is estimated on consumption data before and during crisis years (2006-2011). We exploit the gender-oriented evolution of the economic environment to test original distribution factors. We first allow the sharing rule to depend on regional-time variation in relative unemployment risk during the mancession. Looking more specifically at the gender-differentiated shock from the construction sector, we then suggest a difference-in-difference estimation originally embedded in the structural model. It simply consists in testing the consequence of having a husband in the construction sector after the outburst of the crisis on household resource allocation.

We find that the mancession has strongly impacted the way the resources are shared within the household. On average, the resource share accruing to Spanish wives has increased by around 7-9 percent, following the improvement of their relative opportunities on the labor market. In magnitude, this effect is comparable to the impact of a husband actually becoming unemployed, or of a wife becoming the main earner in the household. The difference-in-difference estimates consolidate our findings and the magnitude of the effect, using individual rather than regional variation.

This study is a first attempt to shed light on the consequences of the economic crisis on the distribution of resources within, and not just between, households. ${ }^{2}$ Using our

\footnotetext{
${ }^{2}$ So far, the existing literature on the mancession essentially focused on measuring the gender gap emerging with the economic crisis, and assessed the vulnerability across different demographic groups (Sierminska and Takhtamanova, 2010; Hoynes et al., 2012; Cho and Newhouse, 2013). While there exists widespread evidence over the redistributive impacts of economic crises between the households, little is known about the changes in the relative welfare of individuals living in these households. Notwithstanding, related studies analyze the likely effect of the mancession on time allocation among spouses (Starr, 2013; Gorsuch, 2016; Heiland et al., 2014; Morrill and Pabilonia, 2015). Probably the closest study to ours is Lacroix and Radtchenko (2011), who analyze the changes in real earnings among Russian couples and how it affected the sharing rule around the 1998 financial crisis. Notably, they focus on labor supply decisions while we focus here on an identification based on consumption data. Other studies have specifically focused on the gender-differentiated effect provided by the collapse of the construction sector: Farré et al. (2015) instrument the unemployment status of individuals with a measure of their
} 
estimates, we compute the evolution of consumption inequality among individuals living in a couple. We document a 5-11 percent decline in overall inequality following the crisis, which is essentially due to intrahousehold redistribution from the mancession. Future work should naturally refine our framework and incorporate other dimensions like risk sharing and joint labor decisions in the household. ${ }^{3}$

The paper is structured as follows. In Section 2, we describe the model and its identification. In Section 3, we present the specification and the data. Results and robustness checks are discussed in Section 4 while section 5 concludes.

\section{Model and Identification}

\subsection{Overview}

Our approach is closely related to the most recent developments of the literature on collective models. While the literature since Chiappori (1988) has mainly provided ingenuous ways to test the model and retrieve the marginal sharing rule (see the survey by Vermeulen (2002)), Browning et al. (2013) and Lewbel and Pendakur (2008) suggest the identification of the complete sharing rule within couples. They exploit data on couples and single-person households simultaneously, together with an assumption of preference stability across demographic groups. ${ }^{4}$ In addition, Browning et al. (2013) model economies of scale for each composite good using Barten scales, which reflect how much each good is jointly consumed by household members. Lewbel and Pendakur (2008) suggest a model which is slightly more restrictive but much more tractable in terms of estimation. They posit a single function representing the economies from joint consumpexposure to the bursting housing bubble in Spain to document the medium run impact of unemployment on their mental health. Aparicio-Fenoll (2016) exploits the exogenous variation in returns to education for males with respect to females induced by the Spanish housing boom to identify their causal impact on enrollment in post-compulsory education and on completion.

${ }^{3}$ Mazzocco (2007), Lise and Yamada (2014) and Theloudis (2015) consider dynamic versions of the collective consumption model.

4 The idea of combining data on people living alone and in couples to retrieve the complete resource sharing rule was already applied in the context of labor supply by Couprie (2007) and calibrated models in a project presented in Laisney et al. (2003). Other applications can also be found in Lise and Seitz (2011), Bargain and Donni (2012) and Cherchye et al. (2012). The assumption of stable preferences across marital status is necessary to make 'situation comparisons' (i.e., compare the welfare of adults when living alone or with others) in the terminology of Pollak (1991). Recent studies attempt to test this assumption. While Brugler (2016) shows that consumer preferences significantly differ across singles and members of couples, Hubner (2017) constructs a nonparametric test of the stable preference assumption and rejects it on Russian data. 
tion and assume it is independent of total expenditure ('independence of base'). With this (testable) simplification, they can identify both resource sharing and economies of scales without observing price variation: the demand system reduces to a mildly nonlinear system of Engel curves, estimated on cross-sectional data.

The model we use is somewhat intermediate. While our six years of data surrounding the crisis are not enough variation to identify Barten scales, we cannot ignore the price variation that has taken place. Hence, we rely on a model similar to Lewbel and Pendakur (2008) but simply control for prices in the model. We use the same basic behavioral identifying assumptions as these authors, namely that individual preferences do not change across household compositions, and the 'independence of base' assumption. This middle ground model is very convenient when using data in which spatial or time variation in prices cannot be ignored but is not big enough to be used for Barten scale identification.

\subsection{Model and Assumptions}

We model decisions about consumption only. Individuals are indexed by subscript $i=$ $m, w$ for men and women respectively while superscript $k=1, \ldots, K$ denotes goods. The $\log$ total expenditure in a household is denoted by $x$ and the vector of log prices by $\boldsymbol{p}$. For a single person, individual log resources simply coincide with household log expenditure $x$. His/her welfare level is represented by:

$$
u_{i}=v_{i}\left(x, \boldsymbol{p}, \boldsymbol{z}_{i}\right)
$$

where $v_{i}\left(\cdot, \boldsymbol{p}, \boldsymbol{z}_{i}\right)$ is a well-behaved indirect utility function and $\boldsymbol{z}_{i}$ is a vector of individual characteristics.

For a couple, we model consumption decisions as a repeated choice for which the assumption of efficiency is plausible. The most general representation of an efficient household decision-making process is the collective approach, which can be seen as a two-stage budgeting process (Browning et al., 1994). In a first stage, household resources are supposed to be allocated between spouses according to a sharing rule, i.e., the outcome of an unspecified decision process. Individual $i$ living in a couple receives a share $\eta_{i}(\boldsymbol{p}, \boldsymbol{z})$ of total expenditure $\exp (x) .{ }^{5}$ In a second stage, expenditures on all goods are chosen as if each individual solved her/his own utility maximization problem subject to her/his individual budget constraint. Individual log resources are equal to:

\footnotetext{
${ }^{5}$ The sharing functions $\eta_{i}(\boldsymbol{p}, \boldsymbol{z}), i=m, w$, are differentiable, comprised between zero and one, and sum up to unity.
} 


$$
x+\log \eta_{i}(\boldsymbol{p}, \boldsymbol{z})-\log s_{i}(\boldsymbol{p}, \boldsymbol{z}),
$$

with the sharing function $\eta_{i}(\boldsymbol{p}, \boldsymbol{z})$ and $s_{i}(\boldsymbol{p}, \boldsymbol{z})$ a function that may represent economies of scale from joint consumption or externalities in consumption. These functions depend on prices and on $\boldsymbol{z}$, a vector of individual and household characteristics. Using the same indirect utility function $v_{i}\left(\cdot, \boldsymbol{p}, \boldsymbol{z}_{i}\right)$ as for single individuals, the indifference curves of spouse $i$ satisfies the condition:

$$
u_{i}=v_{i}\left(x+\log \eta_{i}(\boldsymbol{p}, \boldsymbol{z})-\log s_{i}(\boldsymbol{p}, \boldsymbol{z}), \boldsymbol{p}, \boldsymbol{z}_{i}\right) .
$$

Hence, differences in expenditure patterns between a person living alone and a person living in a couple can be attributed to scaling and sharing functions only. As discussed above, the stability of individual preferences across household types is the key hypothesis behind identification results. The ratio $I_{i}(\boldsymbol{p}, \boldsymbol{z})=\eta_{i}(\boldsymbol{p}, \boldsymbol{z}) / s_{i}(\boldsymbol{p}, \boldsymbol{z})$ defines an indifference scale, i.e. the factor adjusting income of person $i$ in a couple for her/him to reach the same indifference curve as if living alone (Lewbel, 2003). Following Lewbel and Pendakur (2008), we make the second identifying assumption, namely that sharing and scaling functions, and hence indifference scales, do not depend on household total expenditure. ${ }^{6}$ Importantly, household characteristics $\boldsymbol{z}$ in the sharing function possibly include distribution factors $\boldsymbol{z}^{D}$ that affect spouses' relative bargaining position (without influencing preferences or the budget constraint directly). These factors are sometimes used to identify collective models (Bourguignon et al., 2009), which is not the case in our approach. Thus, we are free to incorporate any such factors and, as discussed below, to test the potential role of original environmental factors like the spouses' relative risk of unemployment.

\subsection{Structural Budget Shares}

We now discuss the identification of structural components. For singles, the budget share of individual $i$ for good $k$ is defined by

\footnotetext{
${ }^{6}$ Bargain and Donni (2012) show that identification results still hold, theoretically at least, when sharing functions depend on total expenditure. Also, this assumption can be mitigated in empirical applications by including measures of household wealth other than total expenditure in resource shares. The fact that scaling functions representing scale economies are independent of expenditure - and hence of the utility level - at which they are evaluated is the 'independence of the base' assumption made by Lewbel and Pendakur (2008) in order to retrieve these Engel scales. It is similar to the restriction of the same name in the equivalence scale literature (Lewbel, 1991), but it concerns individual utility functions rather than aggregated household utility functions.
} 


$$
w_{i}^{k}\left(x, \boldsymbol{p}, \boldsymbol{z}_{i}\right)=-\frac{\partial v_{i}\left(x, \boldsymbol{p}, \boldsymbol{z}_{i}\right) / \partial p^{k}}{\partial v_{i}\left(x, \boldsymbol{p}, \boldsymbol{z}_{i}\right) / \partial x},
$$

using Roy's identity. Turning to couples, we can denote log individual resources by $x_{i}=x+\log \eta_{i}$ and apply Roy's identity to equation (3) to define the 'reduced-form' budget share on good $k$ of spouse $i$ as:

$$
\omega_{i}^{k}(x, \boldsymbol{p}, \boldsymbol{z})=-\frac{\partial v_{i}\left(x_{i}-\log s_{i}(\boldsymbol{p}, \boldsymbol{z}), \boldsymbol{p}, \boldsymbol{z}_{i}\right) / \partial p^{k}}{\partial v_{i}\left(x_{i}-\log s_{i}(\boldsymbol{p}, \boldsymbol{z}), \boldsymbol{p}, \boldsymbol{z}_{i}\right) / \partial x_{i}}
$$

This is the fraction of spouse $i$ 's resources spent on good $k$, expressed as a a function of household (log) expenditure $x, \log$ relative prices $\boldsymbol{p}$ and household characteristics $\boldsymbol{z}$. Developing the derivatives on the right-hand side easily leads to:

$$
\omega_{i}^{k}(x, \boldsymbol{p}, \boldsymbol{z})=\lambda_{i}^{k}(\boldsymbol{p}, \boldsymbol{z})+w_{i}^{k}\left(x_{i}-\log s_{i}(\boldsymbol{p}, \boldsymbol{z}), \boldsymbol{p}, \boldsymbol{z}_{i}\right)
$$

where $\lambda_{i}^{k}(\boldsymbol{p}, \boldsymbol{z})=\partial \log s_{i}(\boldsymbol{p}, \boldsymbol{z}) / \partial p^{k}$ is the elasticity of $s_{i}(\boldsymbol{p}, \boldsymbol{z})$ with respect to the $k$-th price. $^{7}$

We denote $W_{n}^{k}$ the household budget share for good $k$ and household type $n=1,2$ for single individuals and couples respectively. For singles, the total budget share for good $k$ is simply defined by

$$
W_{1}^{k}\left(x, \boldsymbol{p}, \boldsymbol{z}_{i}\right)=w_{i}^{k}\left(x, \boldsymbol{p}, \boldsymbol{z}_{i}\right)
$$

For couples, total expenditure on each good $k$ can be written as the sum of individual expenditure $\omega_{i}^{k}(x, \boldsymbol{p}, \boldsymbol{z}) \cdot x_{i}, i=m, w$, on that good. Dividing this identity by the total outlay $\exp (x)$, we directly obtain the couple's budget share function for good $k$ as:

$$
W_{2}^{k}(x, \boldsymbol{p}, \boldsymbol{z})=\sum_{i=m, w} \eta_{i}(\boldsymbol{p}, \boldsymbol{z}) \cdot\left(\lambda_{i}^{k}(\boldsymbol{p}, \boldsymbol{z})+w_{i}^{k}\left(x+\log I_{i}(\boldsymbol{p}, \boldsymbol{z}), \boldsymbol{p}, \boldsymbol{z}_{i}\right)\right) .
$$

This is simply the sum of individual budget share equations weighted by individual resource shares. From the knowledge of the 'basic' budget shares $w_{i}^{k}$ estimated on singles,

\footnotetext{
${ }^{7}$ The right-hand side puts some structure on individual budget shares as a result of the 'independence of the base' restriction, using the 'basic' budget share function $w_{i}^{k}\left(\cdot, \boldsymbol{p}, \boldsymbol{z}_{i}\right)$ defined for single individuals. The consequence of this assumption is that the budget share equations of person $i$ living in a couple differ from when living alone only in that they are translated over by the elasticity $\lambda_{i}^{k}(\boldsymbol{p}, \boldsymbol{z})$ and depend on her/his individual resources adjusted by the scaling $s_{i}(\boldsymbol{z})$. This property of 'shape invariance', as defined by Pendakur (1999), implicitly means that single individuals are used as the demographic structure of reference.
} 
it is possible to retrieve structural components and in particular the resource shares. The proof, in the Appendix, is similar to Bargain and Donni (2012). As in Lewbel and Pendakur (2008), gender-specific goods (male and female clothing) are not necessary for identification but are used to ease the parametric estimation (assignable goods limit multicollinearity issues in the budget shares of men and women, and consequently yield more precise estimates of the share parameters). Generic identification requires budget share equations for exclusive goods to be nonlinear in log total expenditure, at least for some values of $x$. Hence, our functional form must be sufficiently flexible to account for it, and this regularity condition will be checked in a preliminary step of the empirical analysis.

\section{Empirical Implementation}

\subsection{Functional Forms and Estimation}

Functional Forms. We turn to the empirical specification of the model. Our parameterization aims to balance flexibility and empirical tractability. The first component is the 'basic' budget share equation, for which we adopt the following quadratic specification:

$$
\begin{aligned}
w_{i}^{k}\left(x_{i, n}, \boldsymbol{p}, \boldsymbol{z}_{i}\right)=\bar{a}_{i}^{k} & +\sum_{j} a_{i, j}^{k} z_{j}+\sum_{q} b_{i, q}^{k} p_{q}+c_{i}^{k}\left(x_{i, n}-\sum_{j} e_{i, j} z_{j}\right) \\
& +d_{i}^{k}\left(x_{i, n}-\sum_{j} e_{i, j} z_{j}\right)^{2}, \quad \text { for } i=w, m \text { and } k=1, \ldots, K,
\end{aligned}
$$

where $x_{i, 1}=x$ and $x_{i, 2}=x+\log \eta_{i}$. Parameters $\bar{a}_{i}^{k}, a_{i, j}^{k}, b_{i, q}^{k}, c_{i}^{k}, d_{i}^{k}$ and $e_{i, j}$ are specific to individual $i=m, w$ but do not depend on the demographic type $n$ since the 'basic' budget share equations are the same for single women (resp. men) and for women (resp. men) living in a couple. The demographic variables enter the specification both as a translation of budget share equations and as a translation of log scaled expenditure. In order to ease the estimation process, the basic characteristics entering $\sum_{j} e_{i, j} z_{j}$ are mainly dummies, namely age (above 35), education (university degree), nationality (non-EU), living in Madrid/Barcelona, rural area, home ownership, car ownership. $\sum_{j} a_{i, j}^{k} z_{j}$ include the same variables. In addition, we account for the variation of prices by introducing a vector of $\log$ relative prices within each of the budget share equations. ${ }^{8}$ Finally, parameters $c_{i}^{k}$ and $d_{i}^{k}$ account for the rescaled log of total expenditures and its square.

\footnotetext{
${ }^{8}$ We impose homogeneity by expressing all prices relative to the price of the remaining goods. In our simple model with an assignable good and a composite good, Slutsky symmetry mechanically holds because the vector of $\log$ relative prices boils down to a scalar.
} 
Next, we specify the household budget share equations. To account for unobserved factors, we add error terms to the household budget shares previously defined:

$$
\begin{aligned}
\widetilde{W}_{n}^{k}(x, \boldsymbol{p}, \boldsymbol{z})= & W_{n}^{k}(x, \boldsymbol{p}, \boldsymbol{z})+\varepsilon_{n}^{k}, \\
& \text { for } n=1,2 \text { and } k=1, \ldots, K,
\end{aligned}
$$

where $\widetilde{W}_{n}^{k}(\cdot)$ is the stochastic extension of $W_{n}^{k}(\cdot)$. Error terms $\varepsilon_{n}^{k}$ are traditionally interpreted as optimization/measurement errors or unobservable heterogeneity in individual budget shares, scale function and sharing function. For single adults and couples (nonexclusive goods) respectively, household budget share equations are written:

$$
\begin{aligned}
\widetilde{W}_{1}^{k}(x, \boldsymbol{p}, \boldsymbol{z}) & =w_{i}^{k}\left(x, \boldsymbol{z}_{i}\right)+\varepsilon_{1}^{k}, \\
\widetilde{W}_{2}^{k}(x, \boldsymbol{p}, \boldsymbol{z}) & =\sum_{i=m, w} \eta_{i}(\boldsymbol{p}, \boldsymbol{z})\left[\lambda_{i}^{k}(\boldsymbol{p}, \boldsymbol{z})+w_{i}^{k}\left(x-\log I_{i}(\boldsymbol{p}, \boldsymbol{z}), \boldsymbol{p}, \boldsymbol{z}_{i}\right)\right]+\varepsilon_{2}^{k} .
\end{aligned}
$$

Next, the sharing function in couples is specified using the logistic form:

$$
\begin{aligned}
\eta_{w}(\boldsymbol{z}, \boldsymbol{p}) & =\frac{\exp \left(\bar{\beta}+\sum_{j} \beta_{j} z_{j}+\sum_{d} \beta_{d} z_{d}^{D}+\sum_{q} \beta_{q} p_{q}\right)}{1+\exp \left(\bar{\beta}+\sum_{j} \beta_{j} z_{j}+\sum_{d} \beta_{d} z_{d}^{D}+\sum_{q} \beta_{q} p_{q}\right)} \\
\eta_{m}(\boldsymbol{z}, \boldsymbol{p}) & =1-\eta_{w}(\boldsymbol{z}, \boldsymbol{p})
\end{aligned}
$$

where $\bar{\beta}, \beta_{j}, \beta_{d}$ and $\beta_{q}$ are parameters. Variables in $\sum_{j} \beta_{j} z_{j}$ contain age and education dummies for the wife. Age in particular should capture broad differences in modes of intrahousehold decisions across different generations of households. Variables in $\sum_{d} \beta_{d} z_{d}^{D}$ are the distribution factors of interest, commented in detail in Section 3.2 below. More classic distribution factors as used in the literature, notably difference in spouses' age or education levels, were experimented with but never found significant, hence we exclude them from our baseline model. $\beta_{q} p_{q}$ are time-region log relative prices of each good $k$ with respect to the other $K-1$ categories of goods. ${ }^{9}$ Then, the log scaling functions that translate expenditure within the basic budget shares can be written as:

$$
\log s_{i}(\boldsymbol{z}, \boldsymbol{p})=\bar{\alpha}_{i}+\sum_{j} \alpha_{i, j} z_{j}+\sum_{q} \alpha_{i, q} p_{q}, \quad \text { for } i=m, w
$$

where $\bar{\alpha}_{i}, \alpha_{i, j}$ and $\alpha_{i, q}$ are parameters. Concretely, variables in $\sum_{j} \alpha_{i, j} z_{j}$ depends on variables relating to individual $i . \sum_{q} \alpha_{i, q} p_{q}$ are the $\log$ relative prices. Finally, the functions that translate the basic budget shares $\lambda_{i}^{k}(\boldsymbol{z})$ are price elasticities. We do not focus on price effects, the estimation of which is generally challenging, and restrict these terms to be constant:

$$
\lambda_{i}^{k}(\boldsymbol{z})=\bar{\lambda}_{i}^{k}, \quad \text { for } i=m, w \text { and } k=1, \ldots, K .
$$

\footnotetext{
${ }^{9}$ In our simple model, this simply comprises the log relative price of male/female clothing with respect to the composite good for each regional-time cell.
} 
Estimation. The full model is estimated by the iterated SURE method. To account for the likely correlation between the error terms $\varepsilon_{n}^{k}$ in each budget share function and the log total expenditure, each budget share equation is augmented with the 'Wu-Hausman' residuals (Banks et al., 1997; Blundell and Robin, 1999). ${ }^{10}$ Since budget shares sum up to one, $K-1$ household budget share equations are estimated, simultaneously for the three household types.

Formally, the estimation of a two-person model requires at least two good categories, with nonlinear Engel curves differing across individuals and across goods (Lewbel and Pendakur, 2008). As discussed above, the use of assignable goods further improves identification. Thus, we opt for a simple model with $K=3$ goods, namely male/female clothing and a composite good (the rest).

\subsection{Distribution Factors}

To capture the effects of the mancession on the intrahousehold distribution of resources, we adopt two specifications of $\sum_{d} \beta_{d} z_{d}^{D}$.

Relative Unemployment Risk. The first one explores the general effect of the relative gender economic opportunities on the sharing of resources. It is proxied for each yearregion cell using the local gender-relative unemployment risk (men's over women's local rate of unemployment), using unemployment data for individuals aged 20-44 from the Spanish national statistical agency (INE). ${ }^{11}$ That is, we can write:

$$
\sum_{d} \beta_{d} z_{d}^{D}=\beta_{1} u_{r, t}^{r a t i o}+\phi_{r}
$$

where $u_{r, t}^{\text {ratio }}$ is the relative unemployment risk ratio for region $r$ and year $t$, and $\phi_{r}$ a vector of region fixed effects.

Construction Sector (Difference-in-Difference). The second specification exploits the fact that construction was and is by far the most male specific sector (only one worker out of ten is a woman). At the same time, it has been particularly affected by the crisis (Bentolila et al., 2012). Indeed, it represented $11.9 \%$ of the existing jobs in 2006 (10.4\% of the total GDP) against $6.9 \%$ in 2011 (6.8\% of total GDP). As a result, the mancession

\footnotetext{
${ }^{10}$ These are obtained from reduced-form estimations of $x$ on all exogenous variables used in the model plus some excluded instruments (a third order polynomial in household disposable income).

${ }^{11}$ Time and regional variation in gender-specific unemployment rate is also used for Britain by Anderberg et al. (2015) who look at the incidence of domestic violence.
} 
effect proxied by regional variation in the unemployment risk can here be estimated using individual variation in the husband's own risk using the gender-differentiated shock from the construction sector. Figure 2 shows annual trends between 2002 and $2012 .{ }^{12}$ It conveys that for this approach, the relevant cutoff is the year 2008. Thus, we adopt the following difference-in-difference specification:

$$
\sum_{d} \beta_{d} z_{d}^{D}=\beta_{1} \text { constru } u_{i}+\beta_{2} \text { post }_{t}^{2008}+\beta_{3} \text { constru }_{i} \times \text { post }_{t}^{2008} .
$$

Controlling for the effect of being married to a construction worker and of being observed in 2008 and after, we focus on the interaction term, which captures the additional share of resources specifically accruing to spouses of construction workers from 2008 onwards, i.e. women whose relative labor market position has potentially improved compared to their husband's.

Note that we shall consider variants of the baseline model whereby other factors are controlled for in the sharing rule, namely the earnings ratio (a usual distribution factor capturing the effect of the financial balance of power), the actual unemployment status of husband and a dummy for whether the wife is active on the labor market. We discuss the role of these variables later on.

Figure 2 - The Construction Sector in Spain, 2002-2012

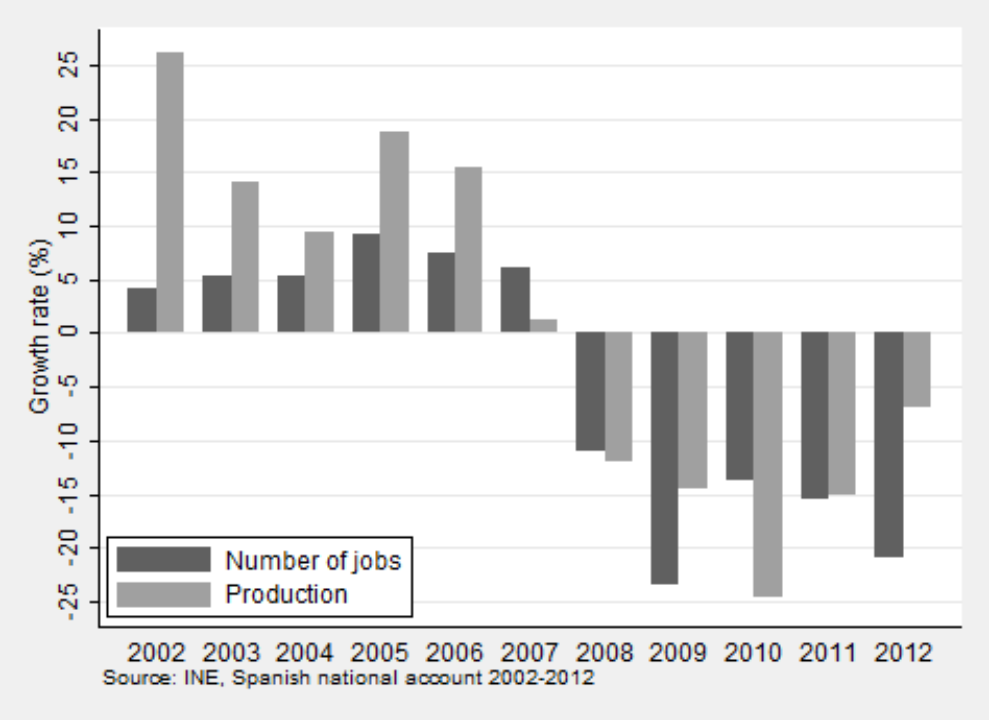

\footnotetext{
${ }^{12}$ The employment reduction in this sector has varied from 18 to $55 \%$ across regions. Ten percentage points of the post-crisis unemployment rate were imputable to the construction sector alone (Pissarides, 2013). The raw correlation between the changes in total and construction employment shares across Spanish regions is 0.70 .
} 


\subsection{Data and Sample Selection}

We use consumption data from the Encuesta de Presupuestos Familiares collected by the INE. The EPF is a nationally representative survey of households living in Spain (around 24,000 households on a yearly basis). It provides information on consumption, labor supply and usual socioeconomic characteristics at the household and individual level. We restrict our analysis to 2006-2011, i.e. three years before and after the breaking point of the end of 2008, treated as repeated cross-sections.

We select single individuals and couples without children living in the home. Couples with children under 16 account for around $23 \%$ of the sample. Other types of families (alone mother or father, or extended families) account for another $40 \%$ of the original sample. This leaves us with $37 \%$ of the original sample (around 48,000 observations over the 6 years). We keep individuals aged 20 to 45, not retirees nor students. Furthermore, we discard couples where the man is ('voluntarily') inactive, which represents only $0.7 \%$ of the selected sample, or for whom information on education or income is missing (3.5\%). Our final selection comprises 8,875 observations, $22.3 \%$ of which are single men, $15.3 \%$ single women, and the remaining $62.4 \%$ childless couples. Note that the second specification of the sharing rule (difference-in-difference approach) requires information on the employment sector of the husband. In the EPF, this information is retrieved only when the husband is declared as the household head (a distinction left to the appreciation of the spouses). This is the case in $76 \%$ of our observations on couple, which we use when implementing our second approach.

Table 1 displays standard statistical information on the individuals and their household. Single individuals without children are older (35 against 32-33 for men and women in couples). While single and married men tend to have a similar education level, single women are more educated than married women. Single and married men tend to have the same level of income. In line with expectation, single women earn less than single men, and married women earn less on average than single women. The mean share of resources brought by the wife to the household is $40 \%$. Around $12 \%$ of single men work in the construction sector, which corresponds to the average share of this sector within the Spanish economy. This share amounts to $17 \%$ of household head men living in a couple. Looking at the bottom part of Table 1, we observe that single women tend to live relatively more in Madrid or Barcelona, while single men and couples are more likely to live in a rural area. Single men are more likely non EU than single women or couples. Home ownership is relatively low for all household types, which is explained by the fact that we look at young, childless individuals and consider home-ownership without pending mortgage payment. Unsurprisingly, couples from the restricted sample 
TABLE 1 - Summary Statistics on Individuals, by Household Types.

\begin{tabular}{|c|c|c|c|c|}
\hline & \multicolumn{3}{|c|}{ Large sample } & \multirow{2}{*}{$\frac{\text { Restricted sample }}{\text { Couples }}$} \\
\hline & Single women & Single men & Couples & \\
\hline \multicolumn{5}{|l|}{ Women } \\
\hline \multirow[t]{2}{*}{ Aged over 35} & 0.46 & & 0.21 & 0.20 \\
\hline & $(0.50)$ & & $(0.41)$ & $(0.40)$ \\
\hline \multirow[t]{2}{*}{ Tertiary education } & 0.62 & & 0.55 & $0.51^{* * *}$ \\
\hline & $(0.49)$ & & $(0.50)$ & $(0.50)$ \\
\hline \multirow[t]{2}{*}{ Income $^{a}$} & 1308.90 & & 993.69 & $869.74^{* * *}$ \\
\hline & $(639.74)$ & & $(639.63)$ & $(591.65)$ \\
\hline \multicolumn{5}{|l|}{ Men } \\
\hline \multirow[t]{2}{*}{ Aged over 35} & & 0.50 & 0.32 & 0.33 \\
\hline & & $(0.50)$ & $(0.47)$ & $(0.47)$ \\
\hline \multirow[t]{2}{*}{ Tertiary education } & & 0.45 & 0.43 & 0.43 \\
\hline & & $(0.50)$ & $(0.50)$ & $(0.49)$ \\
\hline \multirow[t]{2}{*}{ Income $^{a}$} & & 1366.28 & 1367.27 & $1461.94^{* * *}$ \\
\hline & & $(698.79)$ & $(668.56)$ & $(644.13)$ \\
\hline \multirow[t]{2}{*}{ Construction sector } & & 0.12 & & 0.17 \\
\hline & & $(0.33)$ & & $(0.37)$ \\
\hline \multicolumn{5}{|l|}{ Household } \\
\hline \multirow[t]{2}{*}{ Share of wife in total income } & & & 0.40 & $0.34^{* * *}$ \\
\hline & & & $(0.21)$ & $(0.18)$ \\
\hline \multirow[t]{2}{*}{ House ownership, w/o loan } & 0.12 & 0.14 & 0.09 & 0.09 \\
\hline & $(0.32)$ & $(0.35)$ & $(0.28)$ & $(0.28)$ \\
\hline \multirow[t]{2}{*}{ Car ownership } & 0.51 & 0.63 & 0.81 & 0.82 \\
\hline & $(0.50)$ & $(0.48)$ & $(0.39)$ & $(0.39)$ \\
\hline \multirow[t]{2}{*}{ Rural area } & 0.12 & 0.21 & 0.20 & 0.21 \\
\hline & $(0.33)$ & $(0.41)$ & $(0.40)$ & $(0.41)$ \\
\hline \multirow[t]{2}{*}{ Madrid or Barcelona } & 0.13 & 0.11 & 0.10 & 0.10 \\
\hline & $(0.33)$ & $(0.31)$ & $(0.31)$ & $(0.31)$ \\
\hline \multirow[t]{2}{*}{ Foreign } & 0.06 & 0.08 & 0.05 & 0.05 \\
\hline & $(0.24)$ & $(0.27)$ & $(0.21)$ & $(0.21)$ \\
\hline Observations & 1354 & 1978 & 5543 & 4230 \\
\hline
\end{tabular}

Note: Statistics on 2006-2011 EPF sample of working age couples (20-44). ${ }^{a}$ Monthly values. Standard error in parentheses. P-values of difference between restricted and main samples for couples: ${ }^{*} \mathrm{p}<0.1,{ }^{* *} \mathrm{p}<0.05,{ }^{* * *} \mathrm{p}<0.01$.

differ essentially in the fact that wives are less educated, and earn a smaller share of the household income. Otherwise, husbands and households have very similar characteristics in both samples. Table 2, which is discussed hereafter, shows very little difference in expenditure patterns between the main sample and this restricted sample.

\subsection{A First Look at the Consumption Data}

Table 2 presents descriptive statistics on the consumption patterns of the three household types, before and after the outburst of the Great Recession. The first panel displays mean 
total expenditure overall and for selected goods typically used in static consumption models (for instance Lewbel and Pendakur (2008)), essentially corresponding to non-durables. On average, single individuals spend about 20,000 euros on consumption goods, against 31,000 when living in a couple. Once excluding durable goods, investment goods and housing, the total expenditure amounts to 13,000 euros for single-person households, and 23,000 euros for couples. After the outburst of the Great Recession, yearly expenditure significantly drops for all household structures (stars indicate statistical significance of the change over time, per household type).

TABle 2 - Summary Statistics on Budget Shares, by Household Type

\begin{tabular}{|c|c|c|c|c|c|c|c|c|}
\hline & \multicolumn{6}{|c|}{ Main sample } & \multirow{2}{*}{\multicolumn{2}{|c|}{$\frac{\text { Restricted sample }}{\text { Couples }}$}} \\
\hline & \multicolumn{2}{|c|}{ Single women } & \multicolumn{2}{|c|}{ Single men } & \multicolumn{2}{|c|}{ Couples } & & \\
\hline & $\begin{array}{l}2006- \\
2008\end{array}$ & $\begin{array}{l}2009- \\
2011\end{array}$ & $\begin{array}{l}2006- \\
2008\end{array}$ & $\begin{array}{l}2009- \\
2011\end{array}$ & $\begin{array}{c}2006- \\
2008\end{array}$ & $\begin{array}{l}2009- \\
2011\end{array}$ & $\begin{array}{l}2006- \\
2008\end{array}$ & $\begin{array}{l}2009- \\
2011\end{array}$ \\
\hline \multicolumn{9}{|l|}{ Yearly expenditure } \\
\hline Total yearly expenses & 20754 & $19278^{* * *}$ & 21563 & $19546^{* * *}$ & 33303 & $30026^{* * *}$ & 33210 & $29924^{* * *}$ \\
\hline Selected goods ${ }^{+}$ & 19117 & $17661^{* * *}$ & 20110 & $18105^{* * *}$ & 30765 & $27731^{* * *}$ & 30711 & $27645^{* * *}$ \\
\hline W/o housing & 13905 & $12339^{* * *}$ & 15150 & $12778^{* * *}$ & 25138 & $21753^{* * *}$ & 25136 & $21723^{* * *}$ \\
\hline \multicolumn{9}{|l|}{ Budget shares } \\
\hline Food & 0.3083 & 0.3149 & 0.3479 & 0.3453 & 0.3273 & $0.3334^{*}$ & 0.3286 & 0.3349 \\
\hline Transp. and comm. & 0.2333 & 0.2261 & 0.2791 & 0.2676 & 0.2702 & 0.2630 & 0.2694 & 0.2639 \\
\hline Housing services & 0.2019 & 0.2057 & 0.1703 & $0.1832^{* *}$ & 0.1492 & $0.1586^{* * *}$ & 0.1494 & $0.1580^{* * *}$ \\
\hline Leisure & 0.1068 & 0.1007 & 0.0946 & 0.0917 & 0.1052 & $0.0979 * * *$ & 0.1045 & $0.0969^{* * *}$ \\
\hline Vice & 0.0287 & $0.0339^{*}$ & 0.0399 & $0.0501^{* * *}$ & 0.0390 & $0.0435^{* * *}$ & 0.0389 & $0.0437^{* * *}$ \\
\hline Personal care & 0.0567 & 0.0594 & 0.0257 & 0.0236 & 0.0434 & $0.0417^{*}$ & 0.0437 & $0.0414^{*}$ \\
\hline \multicolumn{9}{|l|}{$\begin{array}{c}\text { Assignable good: } \\
\text { yearly expenditures }\end{array}$} \\
\hline Female clothing & 900 & $741^{* * *}$ & 0 & 0 & 957 & $817^{* * *}$ & 956 & $797^{* * *}$ \\
\hline Male clothing & 0 & 0 & 669 & $521^{* * *}$ & 749 & $586^{* * *}$ & 745 & $588^{* * *}$ \\
\hline \multicolumn{9}{|l|}{ Budget shares } \\
\hline Female clothing & 0.0642 & 0.0593 & 0.0000 & 0.0000 & 0.0373 & 0.0361 & 0.0372 & $0.0351 *$ \\
\hline Male clothing & 0.0000 & 0.0000 & 0.0424 & 0.0385 & 0.0284 & $0.0259^{* *}$ & 0.0282 & $0.0261^{*}$ \\
\hline \multicolumn{9}{|c|}{ Proportion of positive values } \\
\hline Female clothing & 0.7859 & 0.7588 & 0.0000 & 0.0000 & 0.7920 & $0.7623^{* * *}$ & 0.7916 & $0.7559^{* * *}$ \\
\hline Male clothing & 0.0000 & 0.0000 & 0.5798 & 0.5429 & 0.6723 & $0.6318^{* * *}$ & 0.6738 & $0.6344^{* * *}$ \\
\hline Observations & 612 & 742 & 871 & 1107 & 2716 & 2827 & 2198 & 2032 \\
\hline
\end{tabular}

Note: $\mathrm{P}$-values of the difference between the two period, ${ }^{*} \mathrm{p}<0.1,{ }^{* *} \mathrm{p}<0.05,{ }^{* * *} \mathrm{p}<0.01 .{ }^{+}$Total expenditure for the non-durable goods.

The second panel of Table 2 presents the shares for non-assignable goods, namely: food and accommodation, transport and communication, housing services, leisure, 'vice' goods (alcohol, tobacco and gambling) and personal care. These budget shares are part of 
the 'composite good' in our model. ${ }^{13}$ We observe that the budget share of typically public goods decreases with the size of the household. This is notably the case with housing services, reflecting substantial economies of scale. The effect of the household size for the other goods, that are partially private and public, is more complicated to interpret (it combines male and female contrasted expenditure patterns and possibly reflects externalities).

The rest of Table 2 reports information on our assignable goods, namely male and female clothing. Expenditure on clothing increases with marriage, but not as fast as total expenditure, which results in decreasing budget shares for both female and male clothing. Importantly, this decline in budget shares is similar for women and men, which is a preliminary indication of the absence of strong unbalance in resource sharing between spouses. Another way to reach this conclusion consists in calculating crude measures of the resource shares accruing to each spouse using clothing expenses. As noted by Lewbel and Pendakur (2008), under the strong assumption that budget shares are independent of the total expenditure and demographic characteristics, the resource shares of married individuals are given by the ratios of budget shares of the assignable goods for married couples versus singles. This gives estimates of resource shares for women (men) equal to $3.73 / 6.42=0.57(2.84 / 4.24=0.67)$ for the first period. These female and male shares violate the natural restriction of shares summing to one. Interestingly, however, the mean share for women increases from 0.57 to 0.61 between 2006-08 and 2009-11, whereas the share for men remains relatively stable. While more realistic estimates are derived in the following section, this already gives an indication of a likely 'mancession' effect.

We end with minor remarks. First, the expenditure pattern does not change radically with the crisis. The budget share devoted to 'vices' and housing expenditures has increased. Expenditure on luxury goods (leisure) has decreased in couples. Absolute expenditure on clothing has dropped significantly during the period while in budget shares, the decline is significant only for men in couple. Part of the decline is explained by an increase in the proportion of zero clothing expenditure. Other statistics are reported in the Appendices. In Appendix B.1, we show Engel curves for the different good categories and check that they are nonlinear in the case of clothing (a requirement of the identification with assignable goods). Finally, data on relative prices are calculated using price data collected by INE.

\footnotetext{
${ }^{13}$ The model being essentially static, we refrain from including expenditure on education or health. This would require adding dynamics and uncertainty in the structural model, which we leave for future research.
} 


\section{Results}

\subsection{Unemployment Risk}

We turn to the core results of our empirical analysis, namely the estimated determinants and magnitude of the sharing rule. We start with our first specification whereby distribution factors include the region-time variation in the men-to-women unemployment ratio. The parameters of the female share are shown in the upper part of Table 3 while the lower part reports estimated female shares under different counterfactual scenarios and when varying different determinants (heterogeneous effects). Model [1] is the baseline specification. Models [2] to [6] test the robustness of the results to alternative specifications and sample sizes. Recall that the sharing rule is a function of the age (above 35) and education (university degree) of the wife, the yearly regional men-women unemployment ratio, as well as region fixed effects and the log regional relative price of clothing. Most specifications show that women above 35 receive a higher share of the resources while higher education is insignificant.

The most salient result for our baseline model [1] is the positive coefficient on the relative unemployment risk. The higher the unemployment rate faced by the husband on the labor market relative to the wife, the higher her consumption share. The effect is significant at the $5 \%$ level. We then use the estimated parameters of the sharing rule to compute the share accruing to a representative Spanish wife in a childless couple around the outburst of the mancession, i.e. for the subperiods 2006-2007 and 2008-2011. The middle part of Table 3 (row 0) reports an initial female share of $41.8 \%$ (i.e. using the mean age, education, relative unemployment ratio and log prices of years 2006-2007). In the 2008-11 period (row 3), the share increases by 3.7 percentage points (i.e. a $9.1 \%$ increase) on average and reaches around $45.6 \%$. To judge how much of this change is due to the mancession, we recalculate the pre-2008 female share when setting the relative unemployment ratios to their 2008-2011 values (row 1). The share of around $44.8 \%$ shows that most of the time variation, around 3 percentage points, is indeed attributed to the improvement in the wives' relative economic opportunities. Alternatively, the 2008-11 share obtained when freezing regional prices to their pre-2008 values (row 2) confirms that the resource shift is due to the evolving unemployment risk, but is not affected by changes in relative prices.

These results hold when varying the specification in models [2] to [6]. Throughout these variants, the share of resources accruing to the wife consistently increases by $6.5-7 \%$ (as reported in the difference between rows 1 and 0 in the middle section of the table), with the exception of model [5] on a subsample of employed individuals giving a slightly larger 
TABlE 3 - Wives' Share

\begin{tabular}{|c|c|c|c|c|c|c|}
\hline \multirow[b]{2}{*}{ Parameters } & \multirow{2}{*}{$\begin{array}{c}\text { Main } \\
{[1]}\end{array}$} & \multicolumn{5}{|c|}{ Robustness } \\
\hline & & {$[2]$} & {$[3]$} & {$[4]$} & {$[5]$} & {$[6]$} \\
\hline Reg. unemploy. ratio & $\begin{array}{c}0.3527^{* *} \\
(0.1393)\end{array}$ & $\begin{array}{c}0.3464^{* *} \\
(0.1394)\end{array}$ & $\begin{array}{c}0.3397^{* *} \\
(0.1386)\end{array}$ & $\begin{array}{c}0.3523^{* *} \\
(0.1393)\end{array}$ & $\begin{array}{c}0.4075^{* *} \\
(0.1738)\end{array}$ & $\begin{array}{c}0.3532^{* *} \\
(0.1399)\end{array}$ \\
\hline Age $\geq 35$ & $\begin{array}{c}0.1326 \\
(0.0812)\end{array}$ & $\begin{array}{c}0.1304 \\
(0.0811)\end{array}$ & $\begin{array}{c}0.1304 \\
(0.0816)\end{array}$ & $\begin{array}{c}0.1320 \\
(0.0812)\end{array}$ & $\begin{array}{c}0.1599^{*} \\
(0.0955)\end{array}$ & $\begin{array}{c}0.1333 \\
(0.0813)\end{array}$ \\
\hline High ed. & $\begin{array}{l}-0.0093 \\
(0.0691)\end{array}$ & $\begin{array}{l}-0.0165 \\
(0.0691)\end{array}$ & $\begin{array}{l}-0.0124 \\
(0.0695)\end{array}$ & $\begin{array}{c}-0.0110 \\
(0.0690)\end{array}$ & $\begin{array}{c}0.0392 \\
(0.0800)\end{array}$ & $\begin{array}{c}-0.0072 \\
(0.0691)\end{array}$ \\
\hline Earning ratio & & $\begin{array}{c}0.1096 * \\
(0.0666)\end{array}$ & & & & \\
\hline Husb. unempl. & & & $\begin{array}{l}0.1016^{* *} \\
(0.0513)\end{array}$ & & & \\
\hline Active & & & & $\begin{array}{c}0.0251 \\
(0.0654)\end{array}$ & & \\
\hline Foreign & & & & & & $\begin{array}{c}0.0560 \\
(0.1026)\end{array}$ \\
\hline Constant & $\begin{array}{l}-0.7187^{* *} \\
(0.2934) \\
\end{array}$ & $\begin{array}{l}-0.7613^{* * *} \\
(0.2952)\end{array}$ & $\begin{array}{l}-0.6596^{* *} \\
(0.2924)\end{array}$ & $\begin{array}{l}-0.7466^{* *} \\
(0.3033)\end{array}$ & $\begin{array}{l}-0.7327^{* *} \\
(0.3403)\end{array}$ & $\begin{array}{l}-0.7549 \text { ** } \\
(0.3004)\end{array}$ \\
\hline Observations & 8875 & 8875 & 8875 & 8875 & 7121 & 8875 \\
\hline Estimated Shares & & & & & & \\
\hline 2006-07 (0) & $\begin{array}{c}0.4185 \\
(0.0628)\end{array}$ & $\begin{array}{c}0.4164 \\
(0.0625)\end{array}$ & $\begin{array}{c}0.4317 \\
(0.0637)\end{array}$ & $\begin{array}{c}0.417 \\
(0.0627)\end{array}$ & $\begin{array}{c}0.4266 \\
(0.0711)\end{array}$ & $\begin{array}{c}0.4115 \\
(0.0633)\end{array}$ \\
\hline 2006-07 (1) & $\begin{array}{c}0.4483 \\
(0.0641)\end{array}$ & $\begin{array}{c}0.4456 \\
(0.0639)\end{array}$ & $\begin{array}{l}0.4606 \\
(0.065)\end{array}$ & $\begin{array}{c}0.4468 \\
(0.0641)\end{array}$ & $\begin{array}{c}0.4612 \\
(0.0727)\end{array}$ & $\begin{array}{c}0.4412 \\
(0.0646)\end{array}$ \\
\hline 2008-11 (2) & $\begin{array}{l}0.4491 \\
(0.064)\end{array}$ & $\begin{array}{c}0.4471 \\
(0.0637)\end{array}$ & $\begin{array}{c}0.463 \\
(0.065)\end{array}$ & $\begin{array}{c}0.4476 \\
(0.0639)\end{array}$ & $\begin{array}{c}0.4625 \\
(0.0725)\end{array}$ & $\begin{array}{c}0.4417 \\
(0.0645)\end{array}$ \\
\hline 2008-11 (3) & $\begin{array}{c}0.4564 \\
(0.0661)\end{array}$ & $\begin{array}{c}0.4544 \\
(0.0659)\end{array}$ & $\begin{array}{l}0.4697 \\
(0.067)\end{array}$ & $\begin{array}{l}0.4549 \\
(0.066)\end{array}$ & $\begin{array}{c}0.4564 \\
(0.0757)\end{array}$ & $\begin{array}{c}0.4489 \\
(0.0665)\end{array}$ \\
\hline $\begin{array}{r}\% \Delta_{(0)-(1)} \\
\% \Delta_{(0)-(3)} \\
\text { Heterogeneous effects (4) }\end{array}$ & $\begin{array}{l}7.12 \\
9.06\end{array}$ & $\begin{array}{l}7.01 \\
9.13\end{array}$ & $\begin{array}{c}6.69 \\
8.8\end{array}$ & $\begin{array}{l}7.15 \\
9.09\end{array}$ & $\begin{array}{l}8.11 \\
6.99\end{array}$ & $\begin{array}{l}7.22 \\
9.09\end{array}$ \\
\hline Earning ratio $0 \%$ & & $\begin{array}{c}0.4164 \\
(0.0625)\end{array}$ & & & & \\
\hline Earning ratio $50 \%$ & & $\begin{array}{c}0.4297 \\
(0.0631)\end{array}$ & & & & \\
\hline Earning ratio $100 \%$ & & $\begin{array}{c}0.4432 \\
(0.0646)\end{array}$ & & & & \\
\hline Husband employed & & & $\begin{array}{c}0.4306 \\
(0.0636)\end{array}$ & & & \\
\hline Husband unemployed & & & $\begin{array}{c}0.4557 \\
(0.0666)\end{array}$ & & & \\
\hline Active & & & & $\begin{array}{l}0.4228 \\
(0.064)\end{array}$ & & \\
\hline Inactive & & & & $\begin{array}{c}0.4167 \\
(0.0627)\end{array}$ & & \\
\hline
\end{tabular}

Note: Standard errors in parenthesis. ${ }^{*} \mathrm{p}<0.1,{ }^{* *} \mathrm{p}<0.05,{ }^{* * *} \mathrm{p}<0.01$. 'Reg. unemploy. ratio' is the men to women regional unemployment ratio. 'Earning ratio' is the women to total earning ratio. All regressions include log relative prices and regional fixed effects. (0) Share computed with 2006-07 averages. (1) Share computed with 2006-07 averages but 2008-11 regional unemployment ratio. (2) Share computed with 2008-11 averages but 2006-07 regional relative prices. (3) Share computed with 2008-11 averages. (4) Heterogenous effects computed with 2006-07 averages. Model [5] is estimated on the subsample of employed men and women. 
increase $(8.1 \%)$.

We now comment each model. Specification [2] allows the sharing process to depend on the actual earning ratio within the couple, calculated as the wife's earnings over total household earnings. This distribution factor is added while still assuming that labor supply decisions are separable from consumption decisions in the household (this is a strong but frequent assumption in the collective model literature, see discussion in Zamora (2011), and our discussion in the concluding section). As expected, we observe that a higher contribution of wives to total household earnings does increase their share of total expenditure. The relative unemployment ratio parameter is robust to the inclusion of the earnings ratio, indicating that labor market opportunities play a specific role, independently from the wives' effective financial power in the couple. To gauge the magnitude of our main effect, the lowest panel of the table reports average pre-crisis (2006-2007) female shares when varying the wife's relative earnings. Interestingly, the fact that an inactive wife becomes the main earner of her household is associated to a 2.7 percentage points increase in her resource share, i.e. a shift of similar order to the mancession effect comparing rows (0) and (1) (3.7).

In model [3], we let the sharing rule depend on the actual unemployment status of the husband. Its coefficient is significant and positive. As discussed in the introduction, the unemployment status of the husband is possibly affected by unobservables that also influence the sharing rule. This argument may be less relevant in times of massive lay-offs, as experienced during the Great Recession in Spain. In any case, it is important to check if our main effect survives to this addition, i.e. if it reflects a psychological impact on the household that is independent from the actual increase in husbands' unemployment. This seems to be the case, as the coefficient on the relative unemployment ratio is barely unchanged. Simulations in the lower part of the table show that the female resource share increases by around 2.5 percentage points, other things being equal, when the husband is unemployed. That is, the increased perceived probability of an adverse shock (the mancession effect) has the same impact on household resource allocation as when the crisis actually hits the household. ${ }^{14}$

\footnotetext{
${ }^{14}$ It is likely that unemployment is more endogenous to the sharing process in a normal situation because of assortative mating and the fact that potential partners internalize each others risk of unemployment before marriage. Inversely, in time of crisis, gender-asymmetric shocks on the labor market may lead to more redistribution as the wife would absorb less of the negative income effect. We check this point in alternative estimations whereby we specify the sharing rule with actual unemployment rates interacted with dummies for pre and post-crisis periods. As hypothesized, we find that the effect of effective unemployment on sharing is indeed very strong during 2009-2011 while statistically inexistent in the pre-crisis period. The coefficient on our variable of interest, the perceived relative unemployment risk, does not change.
} 
Next, macroeconomic fluctuations may trigger changes in women's labor allocations within couples. For instance, the result that we impute to unemployment risk could be driven by a positive correlation between married women's decision to enter the labor market and the widening men-to-women unemployment gap (an added-worker effect). First, the existing empirical evidence does not report any massive labor market re-allocations during hard times in Spain (Congregado et al., 2011). ${ }^{15}$ Second, as a robustness check, model [4] includes participation as a control variable (again assuming separability between consumption and labor supply). Participation has no significant effect on the sharing rule. ${ }^{16}$ Third, an alternative check is provided in model [5], which corresponds to model [1] estimated on a subsample of employed men and women over 2006-2011. ${ }^{17}$ While the initial female share is slightly larger (42.7\%), the mancession effect is still significant and of the same order, with a $9.2 \%$ increase in women's share.

Another legitimate concern relates to migration flows. Internal flows should not be a major issue here. For one thing, they essentially concern single individuals. Moreover, our estimations are carried out on the pooled years while time variation impacts basic budget shares only through price effects. A change in the composition of couple households may be more worrisome, however, and particularly the one driven by immigration and emigration flows. Between 2000-2007, Spain has attracted many labor migrants and offered an active family reunification policy. The outburst of the 2008-2009 crisis severely hit unskilled foreign workers, particularly in the construction sector. Subsequently, Spain has established voluntary return programs for unemployed immigrants and their family. ${ }^{18}$ The migration flows may affect the composition of our sample and bias the results if the family culture of migrants differs substantially from the one of Spanish nationals. Accordingly, we augment the specification of the sharing rule with a dummy for non-EU nationals (model [6]). The results are unchanged.

Next, due to the sharp fall in real interest rates caused by entry to the European Monetary

\footnotetext{
${ }^{15}$ Additionally, aggregate data on labor participation of Spanish women displays no dramatic break around 2008. Women's participation growth rate slightly decreased while remaining positive.

${ }^{16}$ Complementing Bourguignon et al. (1994) with endogenous participation, Zamora (2011) estimates the sharing rule in Spain on the 1990-91 EPF data, and shows that it switches with the participation regime. The extent to which these results differ may be explained by different modeling choices (our approach allows identify the complete sharing process while it includes participation as a simple shifter in the sharing rule specification) and by data selection. Indeed, Zamora focuses on the period 1990-1991 and women aged up to 66 years of age (we focus on childless women aged 20-44 in a much more recent period), which also explain that her share of female participants is as low as $30.1 \%$ (93\% in our sample).

${ }^{17}$ Only employed individuals are selected, both in our main sample of couples and in samples of single men and women used for identification. The sample size of the couple data is reduced by about $30 \%$.

${ }^{18}$ Among men aged 20-44 living in Spain, the proportion of foreign-born decreased from $22 \%$ in 2009 to $19 \%$ in 2014. Source: Own calculation from Cifras de Poblaciòn, INE.
} 
Union and the subsequent housing boom fueled by a credit boom, Spanish households reached the end of the expansion with very high debt, especially in mortgages. This strongly impinged on their consumption in the recession. The impact of the relative unemployment rate on the wives' share may have diverged depending on household indebtedness. The EPF does not provide a debt burden measure (like an interest paymentsto-income ratio) but we can at least control for whether households have mortgage debt (0-1). Adding this variable (not reported) barely affect our estimates of interest. All else being equal, a pending mortgage has a negative effect on the share accruing to wives; however, this effect does not intensify with the relative unemployment risk. ${ }^{19}$

We end with a few comments on the estimated scale economies (Appendix, Table C.3). Recall that the closest the estimated scale is to 1 , the lowest the scale economies. The estimated scales suggest that women benefit from more economies of scale than men within the household. For the average wife, the scale estimate lays between 0.55-0.75. For the average husband, the scale estimate is comprised between 0.88-1.07, with most estimates slightly above 1 ; however, it is imprecisely estimated, and we cannot statistically reject the fact that it may be inferior than $1 .^{20}$ In any case, the fact of changing family structure comes with less scale economies for men than for women.

\footnotetext{
${ }^{19}$ While the model with three goods has the advantage of simplicity and yields robust results, we have also experimented with a richer specification with $\mathrm{K}=8$ goods. While it was expected to increase the efficiency of the estimates, results were not particularly more precise. While the effects of most explanatory variables, including those of interest (relative unemployment risk in the first specification and post $\mathrm{x}$ husband in construction in the second), were similar to those in the model with $\mathrm{K}=3$ goods, the constants were different so that the resource share accruing to the average Spanish woman was larger (between 50 and $60 \%$ depending on the specification). While the reasons for this variability in the sharing rule remain to be explored (see some enlightening in Tommasi and Wolf (2016)), we acknowledge the fact that the estimation of a complete demand system relies on stronger assumptions. More precisely, the identifying assumptions must be satisfied for all the goods and not only for exclusive goods which make it a more demanding condition. The fact that the estimations of the general model were not especially more precise tends to support this explanation. Detailed results are available upon request.

${ }^{20}$ Our scale estimates are in line with the seminal work of Lewbel and Pendakur (2008). In their empirical exercise on the 1990 and 1992 Canadian Family Expenditure Surveys, they find that the average woman benefits from $46 \%$ of the total household resources. The scale economies (computed for the reference category, i.e. high school graduates over 40) are 0.7 for women, and 0.8 for men, but the hypothesis that scales are indeed under 1 cannot be rejected by the data, due to the large standard error associated with the estimate. Other studies (i.e. Bargain and Donni (2012) for France, or Bargain et al. (2013) for Cte dIvoire) find slightly larger scale economies, equally imprecisely estimated.
} 


\subsection{Difference-in-Difference}

We turn to the second strategy aimed at capturing the mancession effect. The construction sector is very representative of a gender-differentiated shock after 2008, which provides household variation to identify this effect.

First, recall that due to data limitation, we conduct this analysis on a restricted sample (i.e. observations where the head is the husband, for whom the sector of activity is available). As discussed in the Data section, budget shares are conform to those observed in our main sample (Table 2) while household characteristics differ a little (Appendix Table 1). To check the consistency of our analysis with this restricted sample, we rerun models [1] and [6] of the previous approach on this sample and compare the estimates we obtain in this case with our previous results using the main sample. This comparison is shown in Appendix C, Table C.1. Results are qualitatively and quantitatively similar, suggesting that the sample change should not be harmful to the validity of our results.

Next, we use our restricted sample for the difference-in-difference approach suggested in Section 3.2. For consistency, Table 4 presents the same specifications as in Table 3, except of course the way we model the mancession effect and regional effects. ${ }^{21}$ Results are comparable across the different models. In particular, education has no effect while age mildly increases the female share.

Focusing on the three coefficients of the double difference, we first see that there is no overall time effect ('Post 2008'). Women whose husband is employed in the construction sector get significantly less resources than the average. Estimates in the lower panel of Table 4 show that before 2008, with model [1], their shares amount to $40.6 \%$ on average, against $44.3 \%$ for women with a husband in another sector. This effect is entirely driven by couples where the husband has a high school degree at most (results not reported). Most importantly, the coefficient on the interaction between time and construction sector is positive and highly significant. ${ }^{22}$ The last row of Table 4 reports the magnitude of the double difference in terms of female resource shares. Women in couple with a construction worker observed in the deep of the recession benefit from an increase in expenditure share

\footnotetext{
${ }^{21}$ Here, we use individual rather than regional variation so that accounting for regional fixed effects is less of a necessity. Keeping them actually leaves the results unchanged.

${ }^{22}$ Note that our measure of construction is not strictly pre-crisis. However, sample selection due to shifts across industries should be limited because for the unemployed, we use information on prior occupation. Sample selection would arise in case of massive reemployment of the newly dismissed construction workers, which is very unlikely in the immediate post-crisis context (see Farré et al. (2015)). In fact, according to aggregate data from INE, the construction sector represents $12.2 \%$ of total employment over 2006-2007, and much less (8.7\%) over 2008-2011. By contrast, in our data, the proportion of husbands in the construction sector is remarkably stable (13.3\% in 2006-2007, $12.1 \%$ afterwards).
} 
TABLE 4 - Wives' Share

\begin{tabular}{|c|c|c|c|c|c|c|}
\hline \multirow[b]{2}{*}{ Parameters } & \multirow{2}{*}{$\begin{array}{c}\text { Main } \\
{[1]}\end{array}$} & \multicolumn{5}{|c|}{ Robustness } \\
\hline & & {$[2]$} & {$[3]$} & {$[4]$} & {$[5]$} & {$[6]$} \\
\hline Husband in construction & $\begin{array}{l}-0.1491^{* *} \\
(0.0699)\end{array}$ & $\begin{array}{l}-0.1516^{* *} \\
(0.0700)\end{array}$ & $\begin{array}{l}-0.1493^{* *} \\
(0.0700)\end{array}$ & $\begin{array}{l}-0.1495^{* *} \\
(0.0701)\end{array}$ & $\begin{array}{l}-0.2326^{* * *} \\
(0.0886)\end{array}$ & $\begin{array}{l}-0.1516^{* *} \\
(0.0707)\end{array}$ \\
\hline Post 2008 & $\begin{array}{l}-0.0169 \\
(0.0518)\end{array}$ & $\begin{array}{l}-0.0164 \\
(0.0518)\end{array}$ & $\begin{array}{l}-0.0167 \\
(0.0518)\end{array}$ & $\begin{array}{l}-0.0168 \\
(0.0518)\end{array}$ & $\begin{array}{l}-0.0319 \\
(0.0604)\end{array}$ & $\begin{array}{l}-0.0168 \\
(0.0518)\end{array}$ \\
\hline Construction $\times$ Post2008 & $\begin{array}{c}0.2203^{* *} \\
(0.0861)\end{array}$ & $\begin{array}{l}0.2210^{* *} \\
(0.0860)\end{array}$ & $\begin{array}{c}0.2216^{* *} \\
(0.0863)\end{array}$ & $\begin{array}{c}0.2204^{* *} \\
(0.0861)\end{array}$ & $\begin{array}{l}0.3332^{* * *} \\
(0.1101)\end{array}$ & $\begin{array}{l}0.2223^{* *} \\
(0.0866)\end{array}$ \\
\hline Age $\geq 35$ & $\begin{array}{c}0.1476 \\
(0.0937)\end{array}$ & $\begin{array}{c}0.1468 \\
(0.0940)\end{array}$ & $\begin{array}{c}0.1476 \\
(0.0937)\end{array}$ & $\begin{array}{c}0.1470 \\
(0.0938)\end{array}$ & $\begin{array}{c}0.1687 \\
(0.1093)\end{array}$ & $\begin{array}{c}0.1478 \\
(0.0936)\end{array}$ \\
\hline High ed. & $\begin{array}{l}-0.0112 \\
(0.0775)\end{array}$ & $\begin{array}{l}-0.0092 \\
(0.0778)\end{array}$ & $\begin{array}{l}-0.0110 \\
(0.0775)\end{array}$ & $\begin{array}{l}-0.0117 \\
(0.0775)\end{array}$ & $\begin{array}{c}0.0591 \\
(0.0865)\end{array}$ & $\begin{array}{l}-0.0102 \\
(0.0776)\end{array}$ \\
\hline Earning ratio & & $\begin{array}{l}-0.0467 \\
(0.1002)\end{array}$ & & & & \\
\hline Husb. unempl. & & & $\begin{array}{l}-0.0149 \\
(0.0764)\end{array}$ & & & \\
\hline Active & & & & $\begin{array}{l}-0.0023 \\
(0.0672)\end{array}$ & & \\
\hline Foreign & & & & & & $\begin{array}{c}0.0274 \\
(0.1098)\end{array}$ \\
\hline Constant & $\begin{array}{l}-0.2857 \\
(0.2795)\end{array}$ & $\begin{array}{l}-0.2474 \\
(0.2887)\end{array}$ & $\begin{array}{l}-0.2921 \\
(0.2801)\end{array}$ & $\begin{array}{l}-0.2785 \\
(0.2918)\end{array}$ & $\begin{array}{l}-0.2211 \\
(0.3048)\end{array}$ & $\begin{array}{l}-0.2924 \\
(0.2863)\end{array}$ \\
\hline Observations & 7562 & 7562 & 7562 & 7562 & 6132 & 7562 \\
\hline Estimated & {$[1]$} & {$[2]$} & {$[3]$} & {$[4]$} & {$[5]$} & {$[6]$} \\
\hline All sectors 2006-07 & $\begin{array}{c}0.4380 \\
(0.0666)\end{array}$ & $\begin{array}{c}0.4428 \\
(0.0674)\end{array}$ & $\begin{array}{c}0.4363 \\
(0.0668)\end{array}$ & $\begin{array}{c}0.4390 \\
(0.0668)\end{array}$ & $\begin{array}{c}0.4590 \\
(0.0744)\end{array}$ & $\begin{array}{c}0.4366 \\
(0.0680)\end{array}$ \\
\hline All sectors $2008-11$ & $\begin{array}{c}0.4521 \\
(0.0695)\end{array}$ & $\begin{array}{c}0.4563 \\
(0.0701)\end{array}$ & $\begin{array}{c}0.4504 \\
(0.0697)\end{array}$ & $\begin{array}{c}0.4529 \\
(0.0697)\end{array}$ & $\begin{array}{c}0.4714 \\
(0.0788)\end{array}$ & $\begin{array}{c}0.4505 \\
(0.0708)\end{array}$ \\
\hline Other sector 2006-07 (a) & $\begin{array}{c}0.4428 \\
(0.0668)\end{array}$ & $\begin{array}{c}0.4478 \\
(0.0675)\end{array}$ & $\begin{array}{c}0.4412 \\
(0.0669)\end{array}$ & $\begin{array}{c}0.4439 \\
(0.0670)\end{array}$ & $\begin{array}{c}0.4667 \\
(0.0744)\end{array}$ & $\begin{array}{c}0.4416 \\
(0.0681)\end{array}$ \\
\hline Other sector 2008-11 (b) & $\begin{array}{c}0.4499 \\
(0.0696)\end{array}$ & $\begin{array}{c}0.4542 \\
(0.0701)\end{array}$ & $\begin{array}{c}0.4482 \\
(0.0697)\end{array}$ & $\begin{array}{c}0.4508 \\
(0.0697)\end{array}$ & $\begin{array}{c}0.4684 \\
(0.0789)\end{array}$ & $\begin{array}{c}0.4484 \\
(0.0708)\end{array}$ \\
\hline Construction 2006-07 (c) & $\begin{array}{c}0.4064 \\
(0.0674)\end{array}$ & $\begin{array}{c}0.4107 \\
(0.0680)\end{array}$ & $\begin{array}{c}0.4048 \\
(0.0676)\end{array}$ & $\begin{array}{c}0.4073 \\
(0.0675)\end{array}$ & $\begin{array}{c}0.4095 \\
(0.0759)\end{array}$ & $\begin{array}{c}0.4046 \\
(0.0691)\end{array}$ \\
\hline Construction 2008-11 (d) & $\begin{array}{c}0.4676 \\
(0.0705)\end{array}$ & $\begin{array}{c}0.4715 \\
(0.0710)\end{array}$ & $\begin{array}{c}0.4661 \\
(0.0706)\end{array}$ & $\begin{array}{c}0.4684 \\
(0.0706)\end{array}$ & $\begin{array}{c}0.4935 \\
(0.0796)\end{array}$ & $\begin{array}{c}0.4659 \\
(0.0719)\end{array}$ \\
\hline$\% \Delta_{A l l}$ & 3.22 & 3.05 & 3.23 & 3.17 & 2.7 & 3.18 \\
\hline$\% \Delta_{\text {Other }}$ & 1.6 & 1.43 & 1.59 & 1.55 & 0.36 & 1.54 \\
\hline$\% \Delta_{\text {Constru }}$ & 15.06 & 14.8 & 15.14 & 15 & 20.51 & 15.15 \\
\hline (d)-(c) ((b)-(a)) & 0.0541 & 0.0544 & 0.0543 & 0.0542 & 0.0823 & 0.0545 \\
\hline
\end{tabular}

Note: Standard errors in parenthesis. ${ }^{*} \mathrm{p}<0.1,{ }^{* *} \mathrm{p}<0.05,{ }^{* * *} \mathrm{p}<0.01$. 'Earning ratio' is the women to total earning ratio. All regressions include log relative prices. Model [5] is estimated on the subsample of employed men and women. 
by $5-6$ percentage points. This magnitude is very similar to what was obtained using timeregional variation in relative unemployment risks. That both approaches, using different sources of variation in relative unemployment risk, lead to very similar estimates brings much confidence in our assessment of the 'mancession effect'. To further assess the robustness of our results, we test for parallel trends by running placebo versions of our main specification. A first estimation is conducted on the sub-period 2006-2007, with a placebo post period 2007. A second is conducted on sub-period 2009-2011, with a placebo post period 2010-11. In both cases, the coefficient on the interaction term between time and construction sector is insignificant, suggesting that trends in sharing between the two groups are indeed otherwise similar.

We add a few ending comments. First, the parameters for the additional variables in models [2] to [4] - the earning ratio, the husband's unemployment and the wife's participation on the labor market - are virtually zero this time. Recall that the restricted sample excludes households headed by women, which limits the range of the earning ratio. Also, the difference-in-difference variables may capture (part of) the husband's unemployment status (we use individual rather than regional variation, and job losses are inextricably related to the construction sector). Second, the results are robust to the sample restriction in model [5]. In line with expectations and previous results, the estimated share for the wives is higher on the subsample of employed individuals. Third, the argument on migration flows developed above is even more relevant for the difference-in-difference approach, because its validity crucially depends on the sample composition over time (and because migrants are disproportionally represented in the construction sector). Results with model [6] reassuringly confirm that migration flows do not confound our estimate. Additional material is provided in the Appendix C, providing detailed results concerning the estimates of the other structural components of the model.

\subsection{Distributional Analysis}

Based on our estimates of the sharing rule, we now compute the resource shares for each couple in our sample and, subsequently, the individual expenditure accruing to each spouse. These annual private resources available to men and women in couple, and their evolution across the period, are described in Table 5. According to our two main models, women lose very little from the crisis ( $2 \%$ in the unemployment risk specification and $3.3 \%$ in the difference-in-difference model). By contrast, men's resources sharply decline due to the cumulative effect of the economic shock and its translation within the household ( $11.8 \%$ and $8.4 \%$ respectively). 
TABLE 5 - Individual Resources and the Evolution of Inter- and Intra-household Inequality

\begin{tabular}{|c|c|c|c|c|}
\hline \multirow[b]{2}{*}{ Indiv. Resources } & \multicolumn{2}{|c|}{ Unemployment risk } & \multicolumn{2}{|c|}{ Difference-in-difference } \\
\hline & Pre & Post & Pre & Post \\
\hline \multicolumn{5}{|l|}{ Mean } \\
\hline Women & 16,276 & 15,956 & 16,595 & 16,040 \\
\hline Men & 20,117 & 17,753 & 19,855 & 18,187 \\
\hline Overall & 18,196 & 16,855 & 18,226 & 17,114 \\
\hline \multicolumn{5}{|l|}{ Std. Dev. } \\
\hline Overall & 7,900 & 7,052 & 7,834 & 7,197 \\
\hline Within couples & 2,305 & 1,156 & 1,957 & 1,316 \\
\hline Between couples & 7,557 & 6,957 & 7,587 & 7,077 \\
\hline$\%$ variance due to within & 8.5 & 2.7 & 6.2 & 3.3 \\
\hline \multicolumn{5}{|l|}{ Theil } \\
\hline Overall & 0.0870 & 0.0825 & 0.0865 & 0.0826 \\
\hline Within couples & 0.0063 & 0.0019 & 0.0046 & 0.0023 \\
\hline$\%$ Theil due to within & 7.2 & 2.3 & 5.3 & 2.8 \\
\hline
\end{tabular}

Note: Annual private resources for individuals living in a couple are calculated using estimates from specifications [1] of Tables 3 and 4, to which (imputed) rents are added.

We turn to the distributional analysis. We report the standard deviation of individual expenditure (sample of couples), for both models and both periods, with a decomposition within and between households. We also report the Theil index and its decomposition (the Theil belongs to the Generalized Entropy Class, the only class of additively decomposable inequality measures).

Actually, few papers have operationalized the collective model to estimate the contribution of intrahousehold inequality to total consumption inequality. A notable exception is Lise and Seitz (2011) who estimate a collective model of consumption on British data over the long period. They find that an increase in marital sorting explains both the rise in consumption inequality between households and the fall in inequality within households since the 1970s in the UK. In the recent period, they report that within-couple inequality contributes to $10-20 \%$ of total inequality, depending on the dispersion measure and model specification. Using our first (second) specification, we find that around 8.5\% $(6.2 \%)$ of the variance and around $7.2 \%(5.3 \%)$ of the inequality in individual expenditure are explained by the extent of within-couple inequality in the pre-crisis period. Strikingly, this share of intrahousehold variance/inequality decreases to around $2-3 \%$ in the second period, i.e. a reduction of 50-65\% in the 'within' component. Another reading of these results shows that the reduction in overall interpersonal inequality (a 8-11\% drop in standard deviation and a 4-5\% drop in the Theil) after the crisis is essentially due to 
the mancession effect, i.e. a reduction of within-couple inequality.

\section{Conclusion}

This paper studies changes in intrahousehold resource allocation among Spanish households during the Great Recession, exploiting the gender-differentiated shock on the labor market (overall and in the construction sector more particularly). A collective model of consumption is estimated on 2006-2011 expenditure data, with two main specifications of the sharing rule. The first one uses time-regional variation in the male-female relative unemployment rate; the second focuses on the particular effect of living with a construction worker post-2008 (a difference-in-difference approach originally embedded in the sharing rule). Both approaches converge in finding a significant 'mancession' effect, i.e. a 7-9\% increase in women's resource share within childless couples. This is a large effect as it is equivalent to a shift in female shares associated with the wife becoming the main earner (or the husband becoming unemployed).

More broadly, this paper contributes to the intrahousehold bargaining literature by combining a structural model and a 'natural experiment' type of approach to estimate the impact of unemployment risk on resource sharing decisions. It is also among the few contributions that operationalize the collective model for distributional analysis. We find that the mancession is responsible for a 50-65\% decrease in within-couple inequality, which translates in a 4-5\% decline in overall inequality. Our study leaves open several interesting questions for future research.

First, our model has assumed that consumption is separable from leisure, as in all the contributions following Browning et al. (2013). We have provided important robustness checks by including participation as a control variable or restricting the sample to twoearner couples. Yet, more effort should be exerted to relax the separability assumption and model labor supply explicitly in this context. Arguably, important complications would arise from doing so: (i) total expenditure would be replaced by a full income that includes the value of leisure, the price of which is not necessarily the market wage (if one spouse is not working on the market); (ii) both the sharing rule and scale economies would now apply to both goods and time consumption, so that their interpretation (as much as that of indifference scales) would change; (iii) modelling non-participation would bring additional difficulties, as it would require an additional equation that may incorporate both the choice of not working on the market and the risk of rationing. Second, the simultaneous occurrence of within-household redistribution and risk-coping mechanisms (like added workers) reopens the question of the (possibly limited) insurance role of the house- 
hold as well as the representation of the household to be adopted in models with adverse shocks (see Chiappori and Mazzocco (2016)). Third, a related issue is the possibility of increased divorce following the relative improvement of women's economic opportunities. In fact, between 2006 and 2011, we find that the number of divorces actually tend to decrease with the crisis. A simple OLS regression between the regional log number of divorces for childless couples and the regional unemployment ratio indicates that divorce and gender relative economic opportunities are not statistically related (this result also holds when controlling for regional and time fixed effects). Nonetheless, more remains to be done to explicitly account for household dissolution in this context. ${ }^{23}$ Last, one may wonder about the long term effects of the mancession, i.e. whether the intrahousehold redistribution documented in this study can persist or whether a recovery bringing the male-female unemployment gap to its initial level would also restore the initial sharing rule.

\section{Compliance with Ethical Standards}

Funding: this study has received no particular funding. Conflict of interest: the authors declare that they have no conflict of interest.

\footnotetext{
${ }^{23} \mathrm{As}$ a matter of fact, very few studies have attempted to endogenize household formation and dissolution in a collective model of consumption. Recently, Mazzocco et al. (2014) study the relationship between household consumption decisions (on labor supply and savings behavior) and marital choices. Cherchye et al. (2014) add the assumption that marriages are stable. They show that combining it and the standard assumption of Pareto-efficiency consumption decisions generates strong testable implications for household consumption patterns.
} 


\section{References}

Anderberg, D., Rainer, H., Wadsworth, J., and Wilson, T. (2015). Unemployment and Domestic Violence: Theory and Evidence. The Economic Journal, forthcoming.

Aparicio-Fenoll, A. (2016). Returns to education and educational outcomes: The case of the spanish housing boom. Journal of Human Capital, 10(2):235-265.

Banks, J., Blundell, R., and Lewbel, A. (1997). Quadratic Engel Curves and Consumer Demand. Review of Economics and Statistics, 79(4):527-539.

Bargain, O. and Donni, O. (2012). The Measurement of Child Costs: A Rothbarth-Type Method Consistent with Scale Economies and Parents Bargaining. European Economic Review, 56(2010-30):792-813.

Bentolila, S., Cahuc, P., Dolado, J. J., and Le Barbanchon, T. (2012). Two-Tier Labour Markets in the Great Recession: France Versus Spain. The Economic Journal, 122(562):155-187.

Blundell, R. and Robin, J. M. (1999). Estimation in Large and Dissaggregated Demand Systems: an Estimator for Conditionally Linear Systems. Journal of Applied Econometrics, 14(3):209-232.

Bourguignon, F., Browning, M., and Chiappori, P.-A. (2009). Efficient Intra-household Allocations and Distribution Factors: Implications and Identification. The Review of Economic Studies, 76(2):503-528.

Browning, M., Bourguignon, F., Chiappori, P.-A., and Lechene, V. (1994). Income and Outcomes: A Structural Model of Intrahousehold Allocation. Journal of Political Economy, 102(6):pp. 1067-1096.

Browning, M., Chiappori, P.-A., and Lewbel, A. (2013). Estimating Consumption Economies of Scale, Adult Equivalence Scales, and Household Bargaining Power. The Review of Economic Studies, 80(4):1267-1303.

Brugler, J. (2016). Testing preference stability between couples and singles. Economics Letters, 142:15-17.

Cherchye, L., De Rock, B., and Vermeulen, F. (2012). Economic Well-Being and Poverty among the Elderly: An Analysis based on a Collective Consumption Model. European Economic Review, 56(6):985-1000. 
Cherchye, L., Demuynck, T., De Rock, B., and Vermeulen, F. (2014). Household Consumption when the Marriage is Stable. Technical report, KU Leuven. DPS 14.08.

Chiappori, P.-A. (1988). Rational Household Labor Supply. Econometrica, 56(1):63-90.

Chiappori, P.-A. and Mazzocco, M. (2016). Static and Intertemporal Household Decisions. Journal of Economic Literature.

Cho, Y. and Newhouse, D. (2013). How did the Great Recession affect Different Types of Workers? Evidence from 17 Middle-Income Countries. World Development, 41:31-50.

Congregado, E., Golpe, A. A., and van Stel, A. (2011). Exploring the Big jump in the Spanish Unemployment Rate: Evidence on an 'Added-Worker' Effect. Economic Modelling, 28(3):1099-1105.

Couprie, H. (2007). Time Allocation within the Family: Welfare Implications of Life in a Couple. The Economic Journal, 117(516):287-305.

Farré, L., Fasani, F., and Mueller, H. (2015). Feeling Useless: The Effect of Unemployment on Mental Health in the Great Recession. IZA Discussion Papers 9235, Institute for the Study of Labor (IZA).

Gorsuch, M. M. (2016). Decomposing the Increase in Men's Time on Childcare during the Great Recession. Review of Economics of the Household, 14(1):53-82.

Heiland, F., Price, J., and Wilson, R. (2014). Maternal Employment and Time Investments in Children. Review of Economics of the Household, pages 1-15.

Hoynes, H., Miller, D. L., and Schaller, J. (2012). Who Suffers During Recessions? The Journal of Economic Perspectives, pages 27-47.

Hubner, S. (2017). Its complicated: A Nonparametric Test of Preference Stability between Singles and Couples.

Lacroix, G. and Radtchenko, N. (2011). The Changing Intra-household Resource Allocation in Russia. Journal of Population Economics, 24(1):85-106.

Laisney, F., Beninger, D., and Beblo, M. (2003). Welfare Analysis of Fiscal Reforms: Does the Representation of the Family Decision Process Matter? Evidence for Germany. Technical report, ZEW Discussion Papers.

Lewbel, A. (1991). Cost of Characteristics Indices and Household Equivalence Scales. European Economic Review, 35(6):1277 - 1293. 
Lewbel, A. (2003). Calculating Compensation in Cases of Wrongful Death. Journal of Econometrics, 113(1):115 - 128.

Lewbel, A. and Pendakur, K. (2008). Estimation of Collective Household Models with Engel curves. Journal of Econometrics, 147(2):350-358.

Lise, J. and Seitz, S. (2011). Consumption Inequality and Intra-household Allocations. The Review of Economic Studies, 78(1):328-355.

Lise, J. and Yamada, K. (2014). Household Sharing and Commitment: Evidence from Panel Data on Individual Expenditures and Time Use. IFS Working Papers W14/05, London.

Mazzocco, M. (2007). Household Intertemporal Behavior: A Collective Characterization and a Test of Commitment. Review of Economic Studies, 74(3):857-895.

Mazzocco, M., Ruiz, C., and Yamaguchi, S. (2014). Labor Supply and Household Dynamics. The American Economic Review, 104(5):354-359.

Morrill, M. S. and Pabilonia, S. W. (2015). What Effects do Macroeconomic Conditions have on the Time couples with Children spend together? Review of Economics of the Household, 13(4):791-814.

Pendakur, K. (1999). Semiparametric Estimates and Tests of Base-Independent Equivalence Scales. Journal of Econometrics, 88(1):1 - 40.

Pissarides, C. A. (2013). Unemployment in the Great Recession. Economica, 80(319):385403.

Pollak, R. A. (1991). Welfare Comparisons and Situation Comparisons. Journal of Econometrics, 50(12):31 - 48.

Sierminska, E. and Takhtamanova, Y. (2010). Job Flows, Demographics and the Great Recession. CEPS/INSTEAD Working Paper Series 2010-41, CEPS/INSTEAD.

Starr, M. A. (2013). Gender, Added-Worker Effects, and the 2007-2009 Recession: Looking within the Household. Review of Economics of the Household, pages 1-27.

Theloudis, A. (2015). Wages and Family Time Allocation. Technical report, mimeo.

Tommasi, D. and Wolf, A. (2016). Overcoming Weak Identification in the Estimation of Household Resource Shares. Working Papers ECARES ECARES 2016-12, ULB Universite Libre de Bruxelles. 
Vermeulen, F. (2002). Collective Household Models: Principles and Main Results. Journal of Economic Surveys, 16(4):533-564.

Zamora, B. (2011). Does Female Participation affect the Sharing Rule? Journal of Population Economics, 24(1):47-83.

\section{A Appendix: Model Identification}

Identification is obtained in two steps. First, the basic budget share functions $w_{i}^{k}\left(\cdot, \boldsymbol{p}, \boldsymbol{z}_{i}\right)$, for any $k$ and $i=m, w$, stem from the estimation of equation (4) on samples of single men and women. They identify the basic budget shares of male and female individuals in couple following the assumption of preferences stability across household types. Second, the resource sharing functions and scaling functions for $n=2$ can be identified from a sample of couples. Precisely, the household budget share equation for good $k$ in a couple can be rewritten as:

$$
W_{2}^{k}(x, \boldsymbol{p}, \boldsymbol{z})=D^{k}(\boldsymbol{p}, \boldsymbol{z})+\sum_{i=m, w} \eta_{i}(\boldsymbol{p}, \boldsymbol{z}) \cdot\left[w_{i}^{k_{i}}\left(x+\log I_{i}(\boldsymbol{z}), \boldsymbol{p}, \boldsymbol{z}_{i}\right)\right],
$$

where $D^{k}(\boldsymbol{p}, \boldsymbol{z})=\sum_{i=m, w} \eta_{i}(\boldsymbol{p}, \boldsymbol{z}) \cdot \lambda_{i}^{k}(\boldsymbol{p}, \boldsymbol{z})$. We first eliminate the good-specific function $D^{k}(\boldsymbol{z})$ by computing the first-order derivative of this expression with respect to $x$ :

$$
\nabla_{x} W_{2}^{k}(x, \boldsymbol{p}, \boldsymbol{z})=\sum_{i=m, w} \eta_{i}(\boldsymbol{p}, \boldsymbol{z}) \nabla_{x} w_{i}^{k}\left(x+\log I_{i}(\boldsymbol{p}, \boldsymbol{z}), \boldsymbol{p}, \boldsymbol{z}_{i}\right),
$$

where the left-hand side is known from the data. In the right-hand side, there are only three unknowns (since resource shares sum up to one): $\eta_{w}, I_{w}$ and $I_{f}$. Generic identification is therefore obtained with at least three different observations for a constant level of $x$. With the use of a gender-specific good $k_{i}$ such as clothing, identification is even strengthen and the formal demonstration is straightforward. Indeed, expression 17 can be rewritten as:

$$
\nabla_{x} W_{2}^{k_{i}}(x, \boldsymbol{p}, \boldsymbol{z})=\eta_{i}(\boldsymbol{p}, \boldsymbol{z}) \nabla_{x} w_{i}^{k_{i}}\left(x+\log I_{i}(\boldsymbol{p}, \boldsymbol{z}), \boldsymbol{p}, \boldsymbol{z}_{i}\right)
$$

for $i=m, w$. Differentiating this expression again with respect to $x$ gives the second-order derivative:

$$
\nabla_{x x} W_{2}^{k_{i}}(x, \boldsymbol{p}, \boldsymbol{z})=\eta_{i}(\boldsymbol{p}, \boldsymbol{z}) \nabla_{x x} w_{i}^{k_{i}}\left(x+\log I_{i}(\boldsymbol{p}, \boldsymbol{z}), \boldsymbol{p}, \boldsymbol{z}_{i}\right)
$$


and taking the ratio of (18) and (19), we have:

$$
\frac{\nabla_{x} W_{2}^{k_{i}}(x, \boldsymbol{p}, \boldsymbol{z})}{\nabla_{x x} W_{2}^{k_{i}}(x, \boldsymbol{p}, \boldsymbol{z})}=\frac{\nabla_{x} w_{i}^{k_{i}}\left(x+\log I_{i}(\boldsymbol{p}, \boldsymbol{z}), \boldsymbol{p}, \boldsymbol{z}_{i}\right)}{\nabla_{x x} w_{i}^{k_{i}}\left(x+\log I_{i}(\boldsymbol{p}, \boldsymbol{z}), \boldsymbol{p}, \boldsymbol{z}_{i}\right)}=\Delta_{i}^{k_{i}}\left(x+\log I_{i}(\boldsymbol{p}, \boldsymbol{z}), \boldsymbol{p}, \boldsymbol{z}_{i}\right)
$$

where function $\Delta_{i}^{k_{i}}(\cdot, \boldsymbol{z})$ is known from the first step. This condition uniquely identifies the indifference scales $I_{i}(\boldsymbol{p}, \boldsymbol{z})$ for $i=m, w$, provided the function $\Delta_{i}^{k_{i}}(\cdot)$ is not periodic in its first argument - a rather natural requirement. Then, for $i=m, w$, identification of sharing functions $\eta_{i}(\boldsymbol{p}, \boldsymbol{z})$ follows from (17) and identification of translation functions $\lambda_{i}^{k_{i}}(\boldsymbol{p}, \boldsymbol{z})$ from (16). Finally, the scaling functions $s_{i}(\boldsymbol{p}, \boldsymbol{z})$ can be computed for $i=m, w$ from the definition of $I_{i}(\boldsymbol{p}, \boldsymbol{z})$.

\section{B Appendix: Empirical Application}

\section{B.1 Engel Curves}

We suggest a visual check of Engel curves in Figure B.1. Food, 'vice' and housing services are necessity goods: holding prices constant, their demand increases with the total expenditure, but less rapidly. Leisure, clothing, personal care and transport are luxury goods, their shares in the total budget increasing with total expenditure. As previously discussed, the generic identification of the model requires the nonlinearity of the budget share equation for assignable goods with respect to the total log expenditure, which seems the case. A formal test is performed in Table B.1. We estimate a reduced form of the model on the subsamples of single individuals and couples, with or without inclusion of Wu-Hausman residuals. Results show that the budget shares for assignable goods are indeed nonlinear with respect to the log of total expenditure. Estimates are not markedly affected by the introduction of WuHausman residuals. We also provide a check for the endogeneity of the total expenditure. 
TABle B.1 - Nonlinearities in Budget Shares of Assignable Goods, by Gender and Household Structure

\begin{tabular}{|c|c|c|c|}
\hline & \multirow[t]{2}{*}{ Linear } & \multicolumn{2}{|c|}{ Quadratic } \\
\hline & & W/o Wu-Hausman & Wu-Hausman \\
\hline \multicolumn{4}{|l|}{ Clothing share, single women } \\
\hline \multirow[t]{2}{*}{ Log yearly expenditure } & $0.00820^{* * *}$ & $0.220^{* * *}$ & $0.227^{* * *}$ \\
\hline & $(0.0028)$ & $(0.0590)$ & $(0.0587)$ \\
\hline \multirow[t]{2}{*}{ Squared log yearly expenditure } & & $-0.0113^{* * *}$ & $-0.0103^{* * *}$ \\
\hline & & $(0.0032)$ & $(0.0031)$ \\
\hline \multirow[t]{2}{*}{ Wu-Hausman residual } & & & $-0.0299^{* * *}$ \\
\hline & & & $(0.0077)$ \\
\hline Observations & 1354 & 1354 & 1354 \\
\hline \multicolumn{4}{|l|}{ Clothing share, single men } \\
\hline \multirow[t]{2}{*}{ Log yearly expenditure } & $0.00988^{* * *}$ & $0.151^{* * *}$ & $0.149^{* * *}$ \\
\hline & $(0.0020)$ & $(0.0403)$ & $(0.0403)$ \\
\hline \multirow[t]{2}{*}{ Squared log yearly expenditure } & & $-0.00752^{* * *}$ & $-0.00762^{* * *}$ \\
\hline & & $(0.0021)$ & $(0.0022)$ \\
\hline \multirow[t]{2}{*}{ Wu-Hausman residual } & & & 0.00437 \\
\hline & & & $(0.0054)$ \\
\hline Observations & 1978 & 1978 & 1978 \\
\hline \multicolumn{4}{|l|}{ Clothing share, women in couple } \\
\hline \multirow[t]{2}{*}{ Log yearly expenditure } & $0.00569^{* * *}$ & $0.151^{* * *}$ & $0.151^{* * *}$ \\
\hline & $(0.0010)$ & $(0.0244)$ & $(0.0243)$ \\
\hline \multirow[t]{2}{*}{ Squared log yearly expenditure } & & $-0.00735^{* * *}$ & $-0.00700^{* * *}$ \\
\hline & & $(0.0012)$ & $(0.0012)$ \\
\hline \multirow[t]{2}{*}{ Wu-Hausman residual } & & & $-0.00825^{* * *}$ \\
\hline & & & $(0.0027)$ \\
\hline Observations & 5543 & 5543 & 5543 \\
\hline \multicolumn{4}{|l|}{ Clothing share, men in couple } \\
\hline \multirow[t]{2}{*}{ Log yearly expenditure } & $0.00637^{* * *}$ & $0.0796^{* * *}$ & $0.0796^{* * *}$ \\
\hline & $(0.0010)$ & $(0.0230)$ & $(0.0230)$ \\
\hline \multirow[t]{2}{*}{ Squared log yearly expenditure } & & $-0.00371^{* * *}$ & $-0.00346^{* * *}$ \\
\hline & & $(0.0012)$ & $(0.0012)$ \\
\hline \multirow[t]{2}{*}{ Wu-Hausman residual } & & & $-0.00600 * *$ \\
\hline & & & $(0.0026)$ \\
\hline Observations & 5543 & 5543 & 5543 \\
\hline
\end{tabular}

Note: Standard errors in parenthesis. P-values: ${ }^{*} \mathrm{p}<0.1,{ }^{* *} \mathrm{p}<0.05,{ }^{* * *} \mathrm{p}<0.01$. Controls : age dummy, high education dummy, rural area dummy, Madrid-Barcelona dummy, dummy for home and car ownership. 
Figure B.1 - Engel Curves, Kernel Weighted Local Polynomial Smoothing
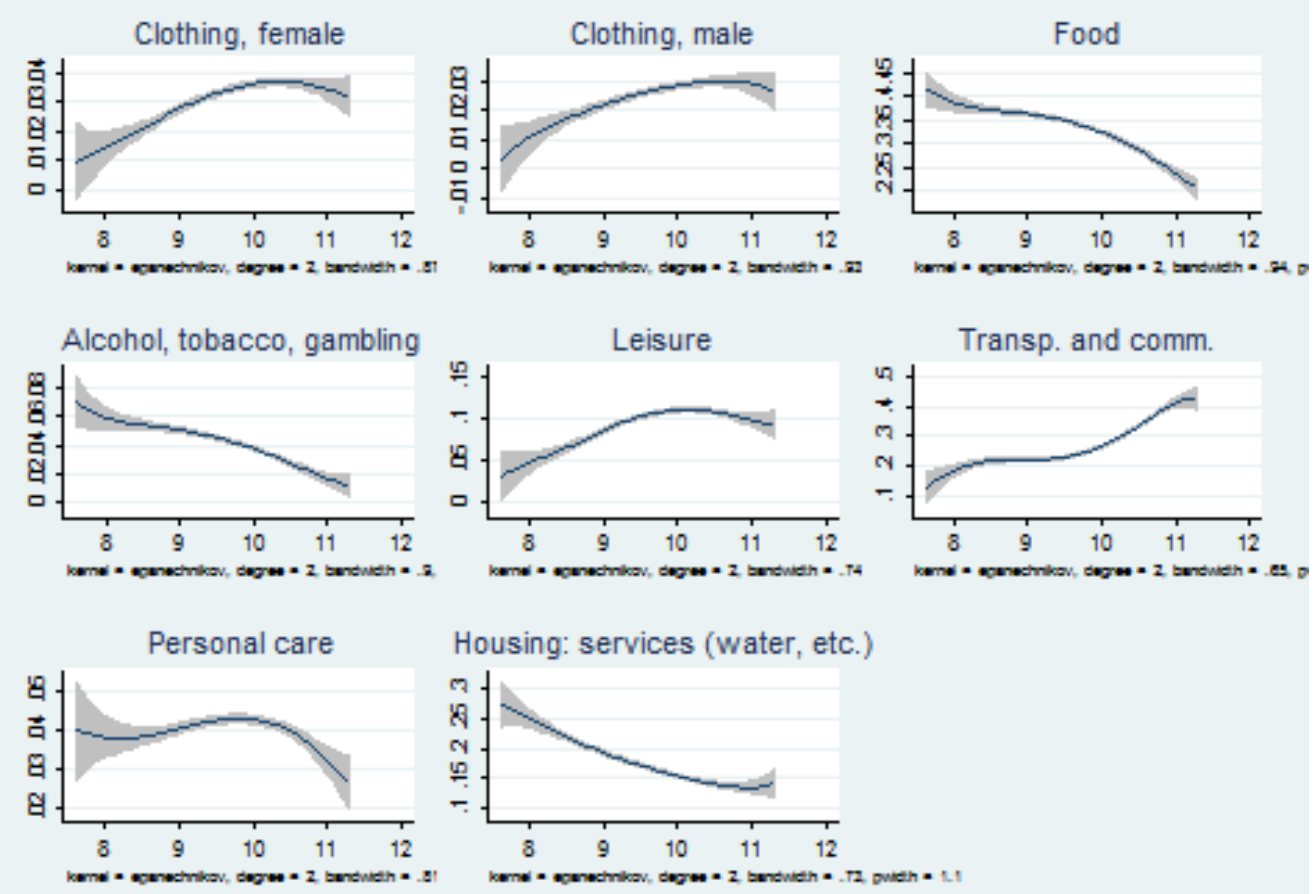

\section{Appendix: Results}

The estimated coefficients for the budget share equations of the baseline model with 3 goods are presented in Table C.2. Men and women's demand for clothing have the same determinants in terms of sign and magnitude. In line with the nonlinearity identification condition, it depends positively on the log of total expenditure, and negatively on its square, for both men and women. Besides, women tend to spend more on clothing items if they live in Madrid or Barcelona, and relatively less if they live in a rural area.

The parameters of the scaling function are reported in Tables C.3 and C.4. The theory predicts economies of scale between the resource share (all the consumption is public) and 1 (private consumption). In other words, the closer the estimated scale to 1 , the lower is the degree of joint consumption (scale economies) in the household. 
TABLE C.1 - Comparing Main and Restricted Samples with the Unemployment Ratio Specification

\begin{tabular}{|c|c|c|}
\hline Share parameters. wife & Main & Restricted \\
\hline \multirow[t]{2}{*}{ Constant } & $-0.7187^{* *}$ & $-0.5911^{*}$ \\
\hline & $(0.2934)$ & $(0.3205)$ \\
\hline \multirow[t]{2}{*}{ Reg. unemploy. ratio } & $0.3527^{* *}$ & $0.5324^{* * *}$ \\
\hline & $(0.1393)$ & $(0.169)$ \\
\hline \multirow[t]{2}{*}{ Age $\geq 35$} & 0.1326 & 0.1511 \\
\hline & $(0.0812)$ & $(0.0936)$ \\
\hline \multirow[t]{2}{*}{ High ed. } & -0.0093 & -0.0154 \\
\hline & $(0.0691)$ & $(0.0773)$ \\
\hline Relative log prices & YES & YES \\
\hline Region FE & YES & YES \\
\hline Observations & 8875 & 7562 \\
\hline
\end{tabular}

Note: Standard errors in parenthesis. $* \mathrm{p}<0.1$, ** $\mathrm{p}<0.05$, *** $\mathrm{p}<0.01$. The demographic characteristics are women's (age, education), except 'Reg. unemploy. ratio', which is the men to women regional unemployment ratio. The restricted sample contains only households whose declared head is the husband (i.e. those for whom the husband's sector of employment is observable). 
TABLE C.2 - Budget Share Parameters

\begin{tabular}{|c|c|c|c|c|}
\hline & \multicolumn{2}{|c|}{ Unemployment risk specification [1] } & \multicolumn{2}{|c|}{ Difference-in-difference specification [1] } \\
\hline & $\begin{array}{l}\text { Budget share } \\
\text { for men clothing }\end{array}$ & $\begin{array}{c}\text { Budget share } \\
\text { for women clothing }\end{array}$ & $\begin{array}{l}\text { Budget share } \\
\text { for men clothing }\end{array}$ & $\begin{array}{c}\text { Budget share } \\
\text { for women clothing }\end{array}$ \\
\hline Constant & $\begin{array}{l}-0.8714^{* * *} \\
(0.1455)\end{array}$ & $\begin{array}{l}-1.4136^{* * *} \\
(0.2393)\end{array}$ & $\begin{array}{l}-0.872^{* * *} \\
(0.1501)\end{array}$ & $\begin{array}{l}-1.4157^{* * *} \\
(0.247)\end{array}$ \\
\hline \multicolumn{5}{|l|}{ Characteristics } \\
\hline Age $\geq 35$ & $\begin{array}{l}-0.0028 \\
(0.0026)\end{array}$ & $\begin{array}{c}0.0023 \\
(0.0057)\end{array}$ & $\begin{array}{l}-0.0028 \\
(0.0025)\end{array}$ & $\begin{array}{c}0.0029 \\
(0.0062)\end{array}$ \\
\hline High ed. & $\begin{array}{c}0.0031 \\
(0.0027)\end{array}$ & $\begin{array}{c}0.004 \\
(0.005)\end{array}$ & $\begin{array}{c}0.0031 \\
(0.0027)\end{array}$ & $\begin{array}{c}0.0049 \\
(0.0053)\end{array}$ \\
\hline Log scaled exp. & $\begin{array}{l}0.1867^{* * *} \\
(0.0313)\end{array}$ & $\begin{array}{l}0.2969^{* * *} \\
(0.0504)\end{array}$ & $\begin{array}{l}0.1873^{* * *} \\
(0.0324)\end{array}$ & $\begin{array}{l}0.2978^{* * *} \\
(0.0522)\end{array}$ \\
\hline Sq.log scaled exp. & $\begin{array}{l}-0.0094^{* * *} \\
(0.0017)\end{array}$ & $\begin{array}{l}-0.0146^{* * *} \\
(0.0027)\end{array}$ & $\begin{array}{l}-0.0095^{* * *} \\
(0.0018)\end{array}$ & $\begin{array}{l}-0.0146^{* * *} \\
(0.0028)\end{array}$ \\
\hline Rural resident & $\begin{array}{l}-0.0006 \\
(0.0028)\end{array}$ & $\begin{array}{l}-0.0104^{* *} \\
(0.0048)\end{array}$ & $\begin{array}{c}0.000 \\
(0.0028)\end{array}$ & $\begin{array}{l}-0.0102^{* *} \\
(0.0052)\end{array}$ \\
\hline Madrid or Barcelona & $\begin{array}{c}0.0036 \\
(0.0045)\end{array}$ & $\begin{array}{c}0.0155^{*} \\
(0.0086)\end{array}$ & $\begin{array}{c}0.0037 \\
(0.0044)\end{array}$ & $\begin{array}{c}0.016^{*} \\
(0.0091)\end{array}$ \\
\hline Home owner & $\begin{array}{c}0.004 \\
(0.0042)\end{array}$ & $\begin{array}{c}0.0021 \\
(0.0076)\end{array}$ & $\begin{array}{c}0.0037 \\
(0.0042)\end{array}$ & $\begin{array}{c}0.0024 \\
(0.0082)\end{array}$ \\
\hline Car owner & $\begin{array}{l}-0.0075^{*} \\
(0.004)\end{array}$ & $\begin{array}{l}-0.0129^{* *} \\
(0.0051)\end{array}$ & $\begin{array}{l}-0.0074^{*} \\
(0.0042)\end{array}$ & $\begin{array}{l}-0.0124^{* *} \\
(0.0054)\end{array}$ \\
\hline Foreign & $\begin{array}{c}0.0073 \\
(0.0046)\end{array}$ & $\begin{array}{c}0.0106 \\
(0.0099)\end{array}$ & $\begin{array}{c}0.0085^{*} \\
(0.0046)\end{array}$ & $\begin{array}{c}0.0125 \\
(0.0114)\end{array}$ \\
\hline Log relative prices & & & & \\
\hline Clothing & $\begin{array}{c}0.0399 * \\
(0.0233)\end{array}$ & $\begin{array}{l}0.1137^{* * *} \\
(0.0335)\end{array}$ & $\begin{array}{c}0.0422^{*} \\
(0.0236)\end{array}$ & $\begin{array}{l}0.1144^{* * *} \\
(0.0338)\end{array}$ \\
\hline Observations & 8875 & 8875 & 7562 & 7562 \\
\hline
\end{tabular}

Note: Standard errors in parenthesis. ${ }^{*} \mathrm{p}<0.1,{ }^{* *} \mathrm{p}<0.05,{ }^{* * *} \mathrm{p}<0.01$. The parameters of the budget shares correspond to specification [1] of Tables 3 and 4. 
TABLE C.3 - Scale Economies - Unemployment Risk Specification

\begin{tabular}{|c|c|c|c|c|c|c|}
\hline \multirow[b]{2}{*}{ Parameters. wife } & \multirow{2}{*}{$\frac{\text { Main }}{[1]}$} & \multicolumn{5}{|c|}{ Robustness } \\
\hline & & {$[2]$} & {$[3]$} & {$[4]$} & {$[5]$} & {$[6]$} \\
\hline Constant & $\begin{array}{l}-0.4614 \\
(0.3357)\end{array}$ & $\begin{array}{l}-0.4899 \\
(0.3381)\end{array}$ & $\begin{array}{l}-0.3684 \\
(0.3336)\end{array}$ & $\begin{array}{l}-0.4769 \\
(0.3380)\end{array}$ & $\begin{array}{l}-0.7952^{* *} \\
(0.4051)\end{array}$ & $\begin{array}{l}-0.4616 \\
(0.3370)\end{array}$ \\
\hline Age $\geq 35$ & $\begin{array}{c}0.0691 \\
(0.1723)\end{array}$ & $\begin{array}{c}0.0667 \\
(0.1736)\end{array}$ & $\begin{array}{c}0.0505 \\
(0.1673)\end{array}$ & $\begin{array}{c}0.0683 \\
(0.1731)\end{array}$ & $\begin{array}{c}0.0906 \\
(0.2299)\end{array}$ & $\begin{array}{c}0.0668 \\
(0.1728)\end{array}$ \\
\hline High ed. & $\begin{array}{l}-0.0953 \\
(0.1621)\end{array}$ & $\begin{array}{l}-0.0964 \\
(0.1632)\end{array}$ & $\begin{array}{l}-0.0889 \\
(0.1571)\end{array}$ & $\begin{array}{l}-0.0965 \\
(0.1629)\end{array}$ & $\begin{array}{l}-0.0458 \\
(0.2036)\end{array}$ & $\begin{array}{l}-0.1016 \\
(0.1632)\end{array}$ \\
\hline Log relative prices & YES & YES & YES & YES & YES & YES \\
\hline Parameters. husband & {$[1]$} & {$[2]$} & {$[3]$} & {$[4]$} & {$[5]$} & {$[6]$} \\
\hline Constant & $\begin{array}{c}0.3367 \\
(0.3354)\end{array}$ & $\begin{array}{c}0.3342 \\
(0.3332)\end{array}$ & $\begin{array}{c}0.2704 \\
(0.3379)\end{array}$ & $\begin{array}{c}0.3244 \\
(0.3340)\end{array}$ & $\begin{array}{l}-0.0466 \\
(0.3653)\end{array}$ & $\begin{array}{c}0.3348 \\
(0.3354)\end{array}$ \\
\hline Age $\geq 35$ & $\begin{array}{l}-0.0315 \\
(0.1754)\end{array}$ & $\begin{array}{l}-0.0222 \\
(0.1740)\end{array}$ & $\begin{array}{l}-0.0100 \\
(0.1790)\end{array}$ & $\begin{array}{l}-0.0236 \\
(0.1751)\end{array}$ & $\begin{array}{c}0.1366 \\
(0.2179)\end{array}$ & $\begin{array}{l}-0.0265 \\
(0.1753)\end{array}$ \\
\hline High ed. & $\begin{array}{c}0.0241 \\
(0.1704)\end{array}$ & $\begin{array}{c}0.0243 \\
(0.1690)\end{array}$ & $\begin{array}{c}0.0363 \\
(0.1740)\end{array}$ & $\begin{array}{c}0.0244 \\
(0.1698)\end{array}$ & $\begin{array}{c}0.1727 \\
(0.2127)\end{array}$ & $\begin{array}{c}0.0275 \\
(0.1703)\end{array}$ \\
\hline Log relative prices & YES & YES & YES & YES & YES & YES \\
\hline Estimated & {$[1]$} & {$[2]$} & {$[3]$} & {$[4]$} & {$[5]$} & {$[6]$} \\
\hline Wife & $\begin{array}{c}0.6911 \\
(0.1889)\end{array}$ & $\begin{array}{c}0.6758 \\
(0.1855)\end{array}$ & $\begin{array}{c}0.7491 \\
(0.2054)\end{array}$ & $\begin{array}{c}0.6818 \\
(0.1874)\end{array}$ & $\begin{array}{c}0.5485 \\
(0.1699)\end{array}$ & $\begin{array}{c}0.6894 \\
(0.1887)\end{array}$ \\
\hline Husband & $\begin{array}{c}1.0737 \\
(0.2906)\end{array}$ & $\begin{array}{c}1.0714 \\
(0.2884)\end{array}$ & $\begin{array}{c}1.0122 \\
(0.2767)\end{array}$ & $\begin{array}{c}1.0613 \\
(0.2863)\end{array}$ & $\begin{array}{c}0.8831 \\
(0.2433)\end{array}$ & $\begin{array}{c}1.0744 \\
(0.2918)\end{array}$ \\
\hline
\end{tabular}

Note: Standard errors in parenthesis. ${ }^{*} \mathrm{p}<0.1,{ }^{* *} \mathrm{p}<0.05,{ }^{* * *} \mathrm{p}<0.01$. 
TABle C.4 - Scale Economies - Difference-in-Difference Specification

\begin{tabular}{|c|c|c|c|c|c|c|}
\hline \multirow[b]{2}{*}{ Parameters. wife } & \multirow{2}{*}{$\begin{array}{c}\text { Main } \\
{[1]}\end{array}$} & \multicolumn{5}{|c|}{ Robustness } \\
\hline & & {$[2]$} & {$[3]$} & {$[4]$} & {$[5]$} & {$[6]$} \\
\hline Constant & $\begin{array}{l}-0.4257 \\
(0.3573)\end{array}$ & $\begin{array}{l}-0.3808 \\
(0.3612)\end{array}$ & $\begin{array}{c}-0.435 \\
(0.3615)\end{array}$ & $\begin{array}{c}-0.421 \\
(0.3594)\end{array}$ & $\begin{array}{c}-0.6216^{*} \\
(0.376)\end{array}$ & $\begin{array}{l}-0.4166 \\
(0.3579)\end{array}$ \\
\hline Age $\geq 35$ & $\begin{array}{c}0.1459 \\
(0.1888)\end{array}$ & $\begin{array}{l}0.1384 \\
(0.187)\end{array}$ & $\begin{array}{c}0.1478 \\
(0.1894)\end{array}$ & $\begin{array}{c}0.1452 \\
(0.1889)\end{array}$ & $\begin{array}{c}0.1476 \\
(0.2247)\end{array}$ & $\begin{array}{l}0.1427 \\
(0.189)\end{array}$ \\
\hline High ed. & $\begin{array}{c}-0.0622 \\
(0.1733)\end{array}$ & $\begin{array}{l}-0.0604 \\
(0.1716)\end{array}$ & $\begin{array}{r}-0.0626 \\
(0.174)\end{array}$ & $\begin{array}{c}-0.063 \\
(0.1734)\end{array}$ & $\begin{array}{c}0.059 \\
(0.1964)\end{array}$ & $\begin{array}{r}-0.0638 \\
(0.174)\end{array}$ \\
\hline Log relative prices & YES & YES & YES & YES & YES & YES \\
\hline Parameters. husband & {$[1]$} & {$[2]$} & {$[3]$} & {$[4]$} & {$[5]$} & {$[6]$} \\
\hline Constant & $\begin{array}{c}0.1989 \\
(0.3558)\end{array}$ & $\begin{array}{c}0.1655 \\
(0.3601)\end{array}$ & $\begin{array}{c}0.2037 \\
(0.3561)\end{array}$ & $\begin{array}{c}0.186 \\
(0.3566)\end{array}$ & $\begin{array}{l}-0.1202 \\
(0.3889)\end{array}$ & $\begin{array}{c}0.1982 \\
(0.3589)\end{array}$ \\
\hline Age $\geq 35$ & $\begin{array}{c}-0.0548 \\
(0.1956)\end{array}$ & $\begin{array}{c}-0.042 \\
(0.1973)\end{array}$ & $\begin{array}{c}-0.0561 \\
(0.1951)\end{array}$ & $\begin{array}{l}-0.0498 \\
(0.1966)\end{array}$ & $\begin{array}{c}0.0057 \\
(0.2356)\end{array}$ & $\begin{array}{l}-0.0511 \\
(0.1954)\end{array}$ \\
\hline High ed. & $\begin{array}{c}0.0389 \\
(0.1902)\end{array}$ & $\begin{array}{l}0.0388 \\
(0.192)\end{array}$ & $\begin{array}{c}0.0377 \\
(0.1899)\end{array}$ & $\begin{array}{c}0.0387 \\
(0.1907)\end{array}$ & $\begin{array}{c}0.2743 \\
(0.2447)\end{array}$ & $\begin{array}{c}0.0385 \\
(0.1901)\end{array}$ \\
\hline Log relative prices & YES & YES & YES & YES & YES & YES \\
\hline Estimated & {$[1]$} & {$[2]$} & {$[3]$} & {$[4]$} & {$[5]$} & {$[6]$} \\
\hline Wife & $\begin{array}{c}0.6839 \\
(0.1943)\end{array}$ & $\begin{array}{c}0.7076 \\
(0.2038)\end{array}$ & $\begin{array}{c}0.6783 \\
(0.1954)\end{array}$ & $\begin{array}{c}0.6846 \\
(0.1956)\end{array}$ & $\begin{array}{c}0.6892 \\
(0.1969)\end{array}$ & $\begin{array}{c}0.6883 \\
(0.1958)\end{array}$ \\
\hline Husband & $\begin{array}{c}1.0506 \\
(0.2875)\end{array}$ & $\begin{array}{c}1.0341 \\
(0.2863)\end{array}$ & $\begin{array}{c}1.0552 \\
(0.2899)\end{array}$ & $\begin{array}{c}1.041 \\
(0.2855)\end{array}$ & $\begin{array}{c}1.0615 \\
(0.2959)\end{array}$ & $\begin{array}{c}1.053 \\
(0.2922)\end{array}$ \\
\hline
\end{tabular}

Note: Standard errors in parenthesis. ${ }^{*} \mathrm{p}<0.1,{ }^{* *} \mathrm{p}<0.05,{ }^{* * *} \mathrm{p}<0.01$. 